\title{
Rapid Synaptic Vesicle Endocytosis in Cone Photoreceptors of Salamander Retina
}

\author{
Matthew J. Van Hook ${ }^{1}$ and Wallace B. Thoreson ${ }^{1,2}$ \\ ${ }^{1}$ Department of Ophthalmology and Visual Sciences and ${ }^{2}$ Department of Pharmacology and Experimental Neuroscience, University of Nebraska Medical \\ Center, Omaha, Nebraska, 68198-5840
}

Following synaptic vesicle exocytosis, neurons retrieve the fused membrane by a process of endocytosis to provide a supply of vesicles for subsequent release and maintain the presynaptic active zone. Rod and cone photoreceptors use a specialized structure called the synaptic ribbon that enables them to sustain high rates of neurotransmitter release. They must also employ mechanisms of synaptic vesicle endocytosis capable of keeping up with release. While much is known about endocytosis at another retinal ribbon synapse, that of the goldfish Mb1 bipolar cell, less is known about endocytosis in photoreceptors. We used capacitance recording techniques to measure vesicle membrane fusion and retrieval in photoreceptors from salamander retinal slices. We found that application of brief depolarizing steps $(<100 \mathrm{~ms})$ to cones evoked exocytosis followed by rapid endocytosis with a time constant $\sim 250 \mathrm{~ms}$. In some cases, the capacitance trace overshot the baseline, indicating excess endocytosis. Calcium had no effect on the time constant, but enhanced excess endocytosis resulting in a faster rate of membrane retrieval. Surprisingly, endocytosis was unaffected by blockers of dynamin, suggesting that cone endocytosis is dynamin independent. This contrasts with synaptic vesicle endocytosis in rods, which was inhibited by the dynamin inhibitor dynasore and GTP $\gamma S$ introduced through the patch pipette, suggesting that the two photoreceptor types employ distinct pathways for vesicle retrieval. The fast kinetics of synaptic vesicle endocytosis in photoreceptors likely enables these cells to maintain a high rate of transmitter release, allowing them to faithfully signal changes in illumination to second-order neurons.

\section{Introduction}

Rod and cone photoreceptors rest at a relatively depolarized membrane potential in the dark and tonically release neurotransmitter at a specialized structure called the synaptic ribbon (Heidelberger et al., 2005; Schmitz, 2009). All neuronal synapses employ some mechanism of compensatory endocytosis to retrieve vesicular membrane following exocytosis. This has the dual effect of preventing unlimited expansion of the presynaptic membrane and maintaining a supply of vesicles for subsequent release. This necessity is especially pronounced at rod and cone ribbon synapses, which require an endocytic mechanism capable of keeping pace with maintained high rates of vesicle fusion (LoGiudice and Matthews, 2007).

Much of what is known about endocytosis at ribbon synapses comes from studies of bipolar cell terminals from goldfish retina. Capacitance recordings, which give a measure of changes in membrane surface area resulting from fusion and retrieval of vesicular membrane, have revealed two kinetic components to endocytosis: a fast component with a time constant of 1-2 s and a slower component with a time constant of 10-20 s (von

Received April 11, 2012; revised 0ct. 5, 2012; accepted 0ct. 9, 2012.

Author contributions: M.J.V.H. and W.B.T. designed research; M.J.V.H. performed research; M.J.V.H. and W.B.T. analyzed data; M.J.V.H. and W.B.T. wrote the paper.

This work was supported by Research to Prevent Blindness and National Institutes of Health Grant EY10542. The authors declare no competing financial interests.

Correspondence should be addressed to Wallace B. Thoreson, University of Nebraska Medical Center, Durham Research Center I, Room 4026, Durham Research Plaza, Omaha, NE68198-5840. E-mail: wbthores@unmc.edu.

DOI:10.1523/JNEUROSCI.1764-12.2012

Copyright $\odot 2012$ the authors $\quad 0270-6474 / 12 / 3218112-12 \$ 15.00 / 0$
Gersdorff and Matthews, 1994a; Neves and Lagnado, 1999). The two rely on different molecular mechanisms (Jockusch et al., 2005, Llobet et al., 2011) and are differentially influenced by calcium, chloride, and hydrostatic pressure (Neves and Lagnado, 1999; Neves et al., 2001; Hull and von Gersdorff, 2004; Heidelberger et al., 2002).

Less is known about endocytosis in rod and cones. Ultrastructural and tracer uptake studies suggest that endocytosis may proceed by a variety of mechanisms involving both uncoated and clathrin-coated vesicles and endosomal sorting (Gray and Pease, 1971; Ripps et al., 1976; Schacher et al., 1976; Schaeffer and Raviola, 1978; Cooper and McLaughlin, 1983). More recent work has indicated that endocytosed vesicles are not processed through endosomes and are quickly reincorporated into the releasable pool following retrieval (Rea et al., 2004). Rod and cone terminals contain dynamin and clathrin (Ullrich and Südhof, 1994; Sherry and Heidelberger, 2005), although labeling for dynamin is fairly weak (Sherry and Heidelberger, 2005). A few studies using capacitance recordings have indicated that endocytosis in rods and cones is fast, with estimates of the time constant being $<1 \mathrm{~s}$ and with endocytosis in cones proceeding slightly faster than in rods (Rieke and Schwartz, 1996; Rabl et al., 2005; Innocenti and Heidelberger, 2008).

In this study, we used capacitance measurement techniques to directly examine synaptic vesicle endocytosis in rods and cones. We found that endocytosis in cones can proceed quite rapidly, with a time constant of $\sim 250 \mathrm{~ms}$. The time constant was largely unaffected by manipulations of the amount or spread of calcium within the presynaptic terminal, although calcium did modulate 
the rate of endocytosis by enhancing excess recovery of membrane. Rapid endocytosis in cones did not appear to involve GTP hydrolysis or dynamin function. In rods, endocytosis was slightly slower and depended on dynamin function. The fast mode of endocytosis in rod and cone photoreceptors may be important for allowing these neurons to maintain high rates of neurotransmitter release over extended periods of time.

\section{Materials and Methods}

Retinal slice. Experiments were performed using vertical slices of retinas of aquatic tiger salamanders (Ambystoma tigrinum; Charles Sullivan, Nashville, TN) of both sexes (18-25 cm in length). Care and handling protocols were approved by the Institutional Animal Care and Use Committee at the University of Nebraska Medical Center. Animals were kept on a $12 \mathrm{~h} \mathrm{light/dark} \mathrm{cycle} \mathrm{at} 4-8$ degrees. One to two hours after the beginning of the dark cycle, salamanders were decapitated, quickly pithed, and enucleated. Details of the retinal slice preparation and wholecell recording are described by Van Hook and Thoreson (2012). Briefly, the anterior segment of the eye, including the lens, was removed and the resulting eyecup was cut into quarters and a piece was placed vitreal side down on a nitrocellulose membrane $(5 \times 10 \mathrm{~mm}$; type AAWP, $0.8 \mu \mathrm{m}$ or $0.4 \mu \mathrm{m}$ pores; Millipore). After adhering to the membrane, the retina was isolated under chilled amphibian superfusate and cut into $125 \mu \mathrm{m}$ slices using a razor blade tissue slicer (Stoelting). Slices were rotated 90 degrees to view the retinal layers and anchored in the recording chamber by embedding the ends of the nitrocellulose membrane in vacuum grease.

Electrophysiology. Recordings were performed on an upright fixedstage microscope (E600FN; Nikon) equipped with a $60 \times$ waterimmersion objective. Slices were superfused at $\sim 1 \mathrm{ml} / \mathrm{min}$ with an oxygenated saline solution containing the following (in $\mathrm{mm}$ ): $116 \mathrm{NaCl}$, $2.5 \mathrm{KCl}, 1.8 \mathrm{CaCl}_{2}, 0.5 \mathrm{MgCl}_{2}, 5$ glucose, and 10 HEPES. The $\mathrm{pH}$ was adjusted to 7.8 with $\mathrm{NaOH}$. Osmolarity was measured with a vapor pressure osmometer (Wescor) and adjusted to 240-245 mOsm. In high$\mathrm{Ca}^{2+}$ experiments, the extracellular solution contained $5 \mathrm{mM} \mathrm{CaCl}_{2}$. We occasionally included niflumic acid $(100-200 \mu \mathrm{M})$ in the extracellular solution to help suppress calcium-activated chloride currents. All chemicals were from Sigma unless indicated otherwise.

Patch pipettes were pulled with a PP-830 or PC-10 vertical pipette puller (Narishige) from borosilicate glass pipettes $(1.2 \mathrm{~mm}$ OD, $0.9 \mathrm{~mm}$ ID, with internal filament; World Precision Instruments) and had resistances of $12-20 \mathrm{M} \Omega$. The pipettes were coated with dental wax to reduce stray capacitance. The standard pipette solution contained the following (in mM): 50 CsGluconate, 40 CsGlutamate, $10 \mathrm{TEACl}, 3.5 \mathrm{NaCl}, 1 \mathrm{CaCl}_{2}$, $1 \mathrm{MgCl}_{2}, 9.4 \mathrm{MgATP}$, and $0.5 \mathrm{GTP}-\mathrm{Na}, 5$ EGTA. The $\mathrm{pH}$ was adjusted to 7.2 with $\mathrm{CsOH}$ and the osmolarity was adjusted to $235-240 \mathrm{mOsm}$. In some experiments, we replaced $5 \mathrm{~mm}$ EGTA with $1 \mathrm{~mm}$ BAPTA, $10 \mathrm{~mm}$ BAPTA, or $0.5 \mathrm{~mm}$ EGTA. No additional calcium was added when we made these replacements. For experiments with high $\mathrm{Cl}^{-}$in the pipette solution, we included $50 \mathrm{~mm} \mathrm{CsCl}$ in place of CsGluconate. Reported voltages were not corrected for liquid junction potentials, measured as $-9 \mathrm{mV}$ for the standard pipette solution and $-7 \mathrm{mV}$ for the high $\mathrm{Cl}^{-}$ solution. Pipettes were filled with internal solution $1-3 \mathrm{~cm}$ up the length of the shaft and positioned at a $22^{\circ}$ angle. The column of solution in the pipette contributes positive hydrostatic pressure, but capillary action of the pipette walls and internal filament counteract and exceed this positive pressure, generating a net negative pressure at the pipette tip when the suction line is open to the atmosphere (Heidelberger et al., 2002). Net negative pressure at the tip was apparent from the movement of debris toward the tip when the suction line was open.

Rods and cones were identified by morphology and recording electrodes were positioned with Huxley-Wall micromanipulators. After establishing a giga-ohm seal, the patch was ruptured with gentle suction. All recordings were conducted in voltage-clamp and most were performed with the Optopatch patch-clamp amplifier (Cairn Research). Capacitance measurements were made using the "track-in" mode of the Optopatch (Johnson et al., 2002), as described previously (Rabl et al., 2005). Briefly, the holding potential was varied sinusoidally at $\sim 500 \mathrm{~Hz}$, $30 \mathrm{mV}$ peak to peak around a holding potential of $-70 \mathrm{mV}$. We blanked output from the phase lock amplifier for $3 \mathrm{~ms}$ after the step and began measurements $30 \mathrm{~ms}$ later to avoid any influence of gating charges and allow time for the phase angle feedback circuitry to settle. We excluded any records with appreciable poststimulus changes in series resistance. Amplifier output of membrane current, membrane capacitance, and access resistance were digitized with a Digidata 1322A (Molecular Devices) and acquired with pClamp 9.2 software (Axon/Molecular Devices). Calcium currents were recorded with a $\mathrm{P} / 8$ leak subtraction protocol. Membrane current was lowpass filtered at $2 \mathrm{kHz}$ and capacitance and access resistance at $100 \mathrm{~Hz}$. Access resistance and membrane capacitance were assessed with the RC compensation circuitry of the Optopatch amplifier. Acceptable recordings were those in which access resistance was $<60 \mathrm{M} \Omega$ and holding current $<200 \mathrm{pA}$. The mean series resistance values were $39.1 \pm 0.5 \mathrm{M} \Omega(N=265)$ for cones and $38.1 \pm 1.5 \mathrm{M} \Omega(N=29)$ for rods. The capacitance of cones and rods averaged $46 \pm 1$ and $25 \pm 1 \mathrm{pF}$, respectively. Membrane capacitance transients were well fit with a single exponential averaging $1.8 \pm 0.1 \mathrm{~ms}(N=33$ cones $)$, indicating that these cells are electrotonically compact.

In a handful of experiments (specified in Results) we recorded capacitance using jClamp software (SciSoft; http://www.scisoftco.com/) and a Multiclamp 700A patch-clamp amplifier (Axon/Molecular Devices). In these experiments, a dual sine wave voltage stimulus (781.3 and 1171.9 $\mathrm{Hz}, 30 \mathrm{mV}$ peak to peak) was applied about the holding potential. Admittance analysis was performed on the fast Fourier transform of the current response every $5.12 \mathrm{~ms}$ to provide estimates of membrane capacitance, series resistance, membrane resistance, and membrane current (Santos-Sacchi et al., 1998).

Pharmacology. In several experiments, we replaced GTP $(0.5 \mathrm{~mm})$ or ATP (9.4 mM) in the pipette solution with GTP $\gamma \mathrm{S}(4 \mathrm{~mm})$ or ATP $\gamma \mathrm{S}(9.4$ $\mathrm{mM}$ ), respectively. A dynamin-amphiphysin inhibitory peptide (QVPSRPNRAP; Tocris Bioscience) was dissolved directly in the standard pipette solution at $750 \mu \mathrm{M}$. This peptide inhibits dynamin-dependent endocytosis by disrupting interactions between dynamin and amphiphysin (Grabs et al., 1997; Shupliakov et al., 1997). Dynasore and Dyngo-4a (Ascent Scientific/Abcam) were diluted 1:1000 in the standard pipette solution or in the extracellular solution from a stock made in dimethylsulfoxide. When introducing drugs via the patch pipette, we waited at least $5 \mathrm{~min}$ before making measurements.

Analysis. Traces were analyzed with pClamp 10 software. The time constant of endocytosis was measured with a single exponential fit of the capacitance trace between the peak and the end of the recording. The rate of endocytosis was calculated as $63 \%$ of the total retrieved membrane divided by the time constant. Unless otherwise noted, data are reported as mean \pm SEM and were considered significant for values of $p<0.05$ as determined with a two-tailed independent Student's $t$ test.

Calculation of calcium profiles. We used a Microsoft Excel-based macro to estimate the diffusion of $\mathrm{Ca}^{2+}$ around open $\mathrm{Ca}^{2+}$ channels in different buffering conditions (Ward and Kenyon, 2000). The parameters for these simulations were the same as those used previously (Mercer et al., 2011).

\section{Results}

\section{Fast endocytosis in cones}

To characterize endocytosis in cones, we used capacitance recording techniques, which provide a high temporal resolution estimate of changes in membrane surface area associated with fusion and retrieval of synaptic vesicles. To do this, individual cones were voltage-clamped at $-70 \mathrm{mV}$ and release was evoked by a step to $-10 \mathrm{mV}$ for $25 \mathrm{~ms}$ (Fig. $1 A$ ). This depolarization fully activates the L-type calcium current in cone terminals (Barnes and Hille, 1989) and is sufficient to deplete the entire readily releasable pool (RRP) of synaptic vesicles (Rabl et al., 2005; Bartoletti et al., 2010). This stimulus evoked an average capacitance change of $174 \pm 12 \mathrm{fF}(N=28)$. Assuming a single-vesicle capacitance of $57 \mathrm{aF}$ and 13 ribbons per cone (Thoreson et al., 2004; Pang et al., 2008; Bartoletti et al., 2010), this corresponds to 234 vesicles per ribbon, larger than the RRP estimated from 

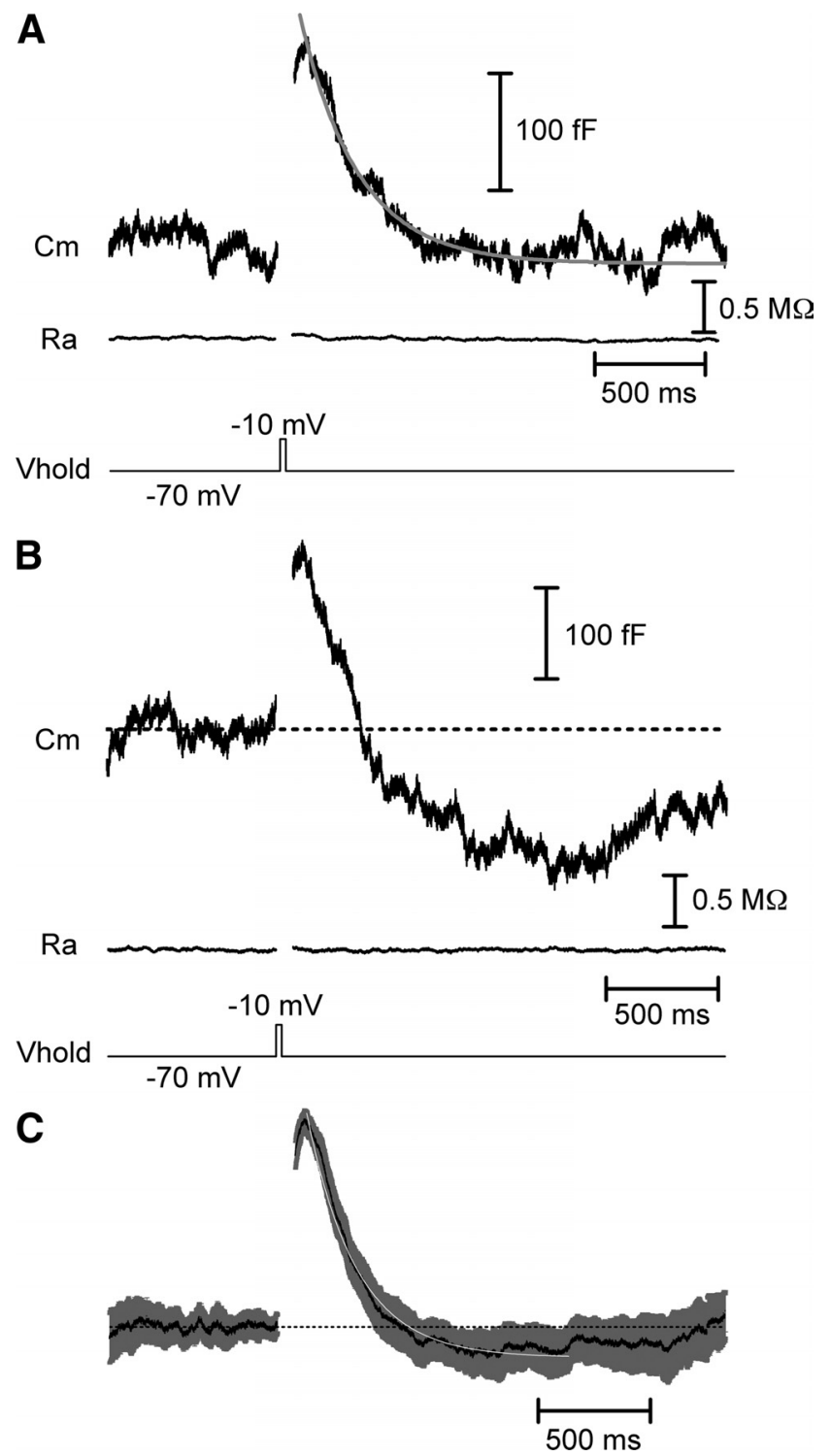

Figure 1. Fast endocytosis in cones. Whole-cell capacitance recordings from cones in a salamander retinal slice preparation. $A$, A 25 ms step depolarization to $-10 \mathrm{mV}$ from a holding potential of $-70 \mathrm{mV}$ evoked an increase in membrane capacitance from fusion of synaptic vesicles. The capacitance trace returned to baseline indicative of endocytosis. The decline of the capacitance trace could be fit with a single exponential function with a time constant $(\tau)$ of 257 $\mathrm{ms}$. The baseline access resistance ( $\mathrm{Ra}$ ) was $32.5 \mathrm{M} \Omega$ and the baseline membrane capacitance $\left(C_{\mathrm{m}}\right)$ was $32.1 \mathrm{pF}$. The displayed trace is an average of three traces from a single cone. $\boldsymbol{B}, \mathrm{As}$ in $\boldsymbol{A}$, capacitance response to a $25 \mathrm{~ms}$ depolarization. In this recording, the capacitance trace overshot the baseline, reflecting excess endocytosis. Baseline values: $C_{m}=36.3 \mathrm{pF}, \mathrm{Ra}=37.9 \mathrm{M} \Omega$. C, Mean (black) and SEM (gray) of 41 normalized capacitance traces fit with a single exponential (white, $\tau=221 \mathrm{~ms}$ ). Vhold, holding potential.

paired cone-horizontal cell recordings (84-134 vesicles per ribbon; Bartoletti et al., 2010). A plateau was often apparent at the peak of the depolarization-evoked capacitance increase. Similar plateaus have been observed in other capacitance recordings from salamander cones (Rowan et al., 2010), retinal bipolar cells (von Gersdorff and Matthews, 1994b), and the calyx of Held (Wu et al., 2009). This plateau may represent a brief inhibition of endocytosis by elevated intracellular calcium (von Gersdorff and Matthews, 1994b) or a period of asynchronous vesicle release when exocytosis and endocytosis remain balanced (von Gersdorff et al., 1998; Singer and Diamond, 2003).
Following the exocytotic capacitance increase, the capacitance signal declined back to baseline, reflecting retrieval of membrane by endocytosis. This decline could be fit by a single exponential with a time constant $(\tau)$ of $225 \pm 18 \mathrm{~ms}(N=28)$. In some cases, the capacitance signal overshot the baseline so the average amount of recovered membrane slightly exceeded the amount of membrane added by vesicle fusion (Fig. $1 B, C$ ), indicative of excess endocytosis (Artalejo et al., 1995, 1996; Renden and von Gersdorff, 2007; Wu et al., 2009). The capacitance signal often crept back toward baseline after the overshoot, suggesting the existence of some mechanism for maintaining homeostasis of the presynaptic membrane (Fig. $1 B, C$ ).

This fast time course of endocytosis corresponds to a rate of retrieval of $621 \pm 70 \mathrm{fF} / \mathrm{s}$, or $837 \pm 95$ vesicles/s/ribbon. This is considerably faster than the sustained release rate evoked by maintained depolarization to $-10 \mathrm{mV}$ in cones ( $\sim 90$ vesicles/s/ ribbon; Bartoletti et al., 2010), indicating that cone endocytosis is capable of keeping up with very high rates of vesicle release. We performed several additional experiments to ensure that the capacitance signals we observed represent genuine exocytosis and endocytosis. First, in some experiments, we included niflumic acid (100-200 $\mu \mathrm{M})$ in the superfusate to suppress the calciumactivated chloride current $\left(I_{\mathrm{Cl}(\mathrm{Ca})}\right)$. In experiments in which this current was completely blocked (Fig. 2A), we still observed a capacitance jump following a step depolarization. The time course by which the capacitance signal returned to baseline was unaffected by the blockade of $I_{\mathrm{Cl}(\mathrm{Ca})}(\tau=254 \pm 28 \mathrm{~ms} ; N=16$; $p=0.40)$. In recordings in which $I_{\mathrm{Cl}(\mathrm{Ca})}$ was preserved by omission of niflumic acid, inhibiting exocytosis by emptying the releasable pool with a train of strong depolarizing pulses abolished the capacitance response despite the persistence of a prominent $I_{\mathrm{Cl}(\mathrm{Ca})}$ (Fig. 2B). With pairs of test pulses $(25 \mathrm{~ms},-70$ to $-10 \mathrm{mV})$ separated by $100 \mathrm{~ms}$ intervals, the second capacitance response was significantly depressed $\left(\Delta C \mathrm{~m}_{2} / \Delta C \mathrm{~m}_{1}=0.40 \pm 0.04 ; N=22\right)$ due to a paired pulse depression of exocytosis (Rabl et al., 2006). $I_{\mathrm{Cl}(\mathrm{Ca})}$ tail currents exhibited significantly less paired pulse depression than capacitance jumps $\left(I_{\mathrm{Cl}(\mathrm{Ca}) 2} / I_{\mathrm{Cl}(\mathrm{Ca}) 1}=0.71 \pm 0.03\right.$; $N=22 ; p<0.000001$, paired $t$ test) and the paired pulse ratios of capacitance jumps and $I_{\mathrm{Cl}(\mathrm{Ca})}$ did not correlate significantly among individual cells $\left(r^{2}=0.10 ; p=0.15\right.$; Pearson correlation), providing further evidence for independence of capacitance responses from $I_{\mathrm{Cl}(\mathrm{Ca})}$. Other results from our laboratory also provide evidence that the depolarization-evoked capacitance increase in cones and its return to baseline are due to exocytosis followed by endocytosis. These include a close match between the kinetics of exocytosis measured from capacitance jumps and postsynaptic currents evoked by cone depolarization (Rabl et al., 2005), linear correlation between postsynaptic current charge transfer and exocytotic capacitance changes (Rabl et al., 2005; Bartoletti et al., 2010), time-dependent rundown of capacitance jumps but not $I_{\mathrm{Cl}(\mathrm{Ca})}$ tail currents during whole-cell recording (Rabl et al., 2005), and the absence of any capacitance change resulting from a large change in membrane resistance with a model cone cell (Rabl et al., 2005). Finally, we also recorded from cones using a dual sine wave protocol for capacitance measurements implemented with jClamp software (Santos-Sacchi et al., 1998). Dual sine wave protocols are particularly resistant to artifacts introduced by changes in membrane conductance (Gillis, 2009; Schnee et al., 2011). In these recordings $(N=11)$, the time constant of the averaged capacitance signal was $\sim 200 \mathrm{~ms}$, similar to the kinetics obtained with the Optopatch amplifier. Together, these data indicate that the depolarization-evoked capacitance increase was due to exocytosis and not to a conductance change. 
A

B
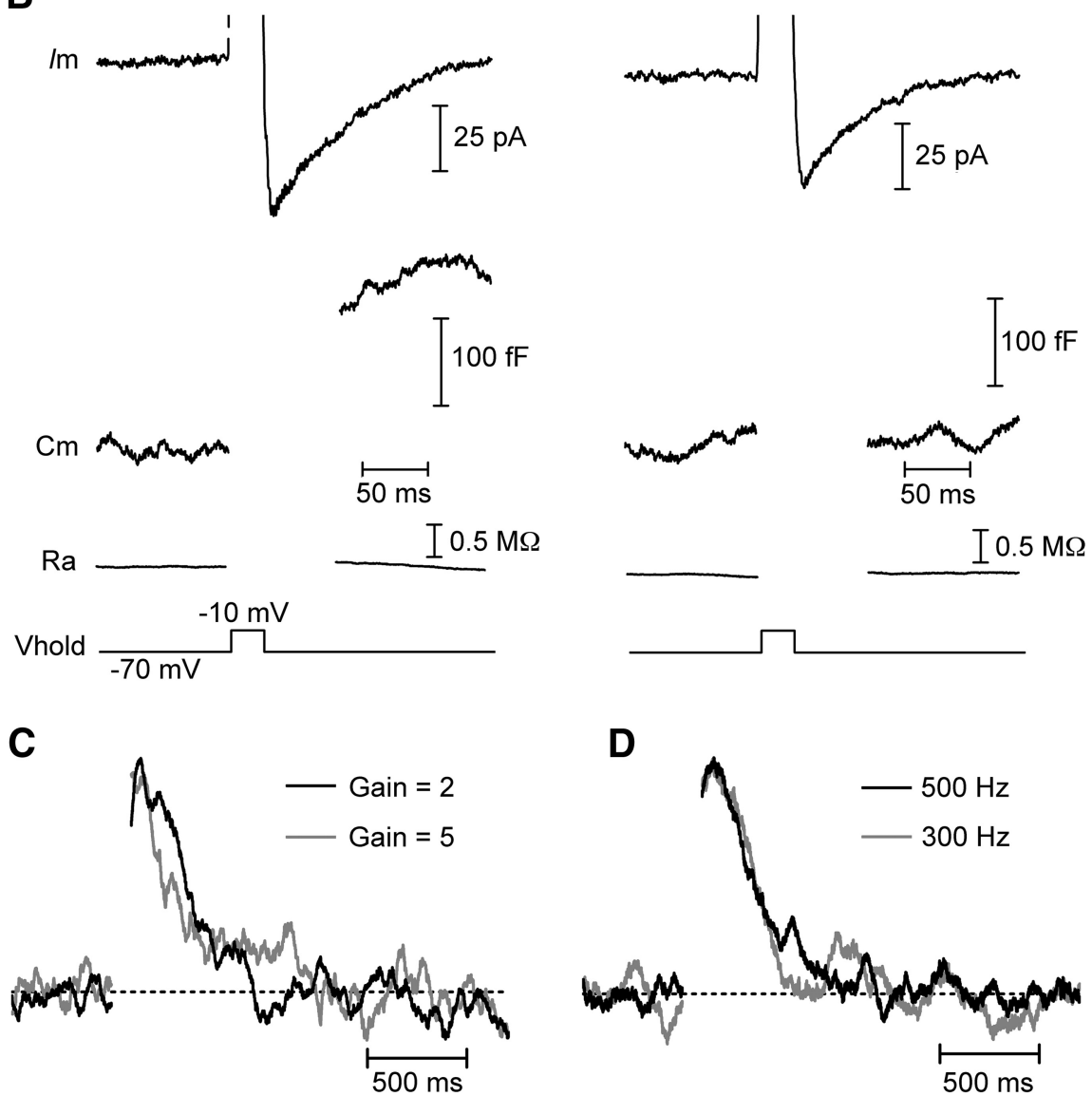

Figure 2. Capacitance responses are not conductance or amplifier artifacts. Whole-cell recordings from cones in salamander retinal slice. $A, B$, Capacitance changes are independent of the calcium-activated chloride tail current, $I_{\mathrm{CI}(\mathrm{Ca})} \cdot A, A$ capacitance change $\left(C_{m}\right)$ was triggered by a $25 \mathrm{~ms}$ step depolarization from -70 to $-10 \mathrm{mV}$ when $I_{\mathrm{CI}(\mathrm{Ca})}$ was completely blocked by niflumic acid $(200 \mu \mathrm{m})$ in the superfusate. Baseline values: $C_{\mathrm{m}}=41.2 \mathrm{pF}$, Ra $=50.0 \mathrm{M} \Omega$. $B$, In the absence of niflumic acid, a $25 \mathrm{~ms}$ depolarizing pulse evoked a large $I_{\mathrm{CI}(\mathrm{Ca})}$ and change in capacitance (left). Following a $1 \mathrm{~s}$ pulse train ( $25 \mathrm{~ms}$ steps to $-10 \mathrm{mV}$ at 13.3 $\mathrm{Hz}$ ) to empty the releasable pool of vesicles, another depolarizing pulse did not evoke an exocytotic capacitance change despite the presence of a prominent $I_{\mathrm{CI}(\mathrm{Ca})}\left(\right.$ right). Baseline $C_{\mathrm{m}}=48.2 \mathrm{pF}, \mathrm{Ra}=38.1 \mathrm{M} \Omega$. C, D, Normalized capacitance responses showing that the time course of endocytosis was unaffected when the gain of the amplifier was switched from 2 to $5(C)$ or when the frequency of the sine wave used for capacitance measurements was decreased to $300 \mathrm{~Hz}$ from $500 \mathrm{~Hz}$ (D). Vhold, holding potential; $\mathrm{Ra}$, access resistance.
The gain setting of the Optopatch amplifier used for capacitance recordings affects the speed at which the circuitry responds to changes in resistance or capacitance (Johnson et al., 2002). To ensure that the time course of capacitance recovery was not influenced by the gain setting, we switched between two gain settings while making capacitance recordings (Fig. 2C). As expected, this manipulation changed the rise time of the capacitance response to a step depolarization, quickening it at higher gains (Johnson et al., 2002). However, the time course of capacitance recovery was unaffected. Additionally, we made several recordings in which we alternated between using 500 and $300 \mathrm{~Hz}$ sine waves (Fig. 2D) for capacitance measurements. This manipulation had no effect on capacitance responses, confirming that the $500 \mathrm{~Hz}$ sine wave was adequate for recording capacitance changes in our experiments.

\section{Role of calcium and endocytic load}

We next undertook a series of experiments to test whether intracellular calcium levels or the amount of exocytosed membrane might regulate the time constant or amount of endocytosis in cones. In the first of these experiments, we triggered release using depolarizing steps from a holding potential of $-70 \mathrm{mV}$ to a series of test potentials from $-40 \mathrm{mV}$ to $-10 \mathrm{mV}$ (Fig. $3 A, B$ ). These test potentials span a range from the activation threshold to the peak of the L-type calcium current in cone photoreceptors such that stronger depolarization results in greater calcium influx and greater release of glutamate (Thoreson et al., 2004; Rabl et al., 2006). Because weaker steps evoked minimal release, we averaged several traces to measure the time course of endocytosis in these experiments. Although stronger depolarization elicited larger exocytotic capacitance increases, the time constants for endocytosis were similar for the different test potentials (Fig. $3 B ;-40 \mathrm{mV}, \tau=260$ $\mathrm{ms}, N=26 ;-30 \mathrm{mV}, \tau=234 \mathrm{~ms}, N=23$; $-20 \mathrm{mV}, \tau=282 \mathrm{~ms}, N=23 ;-10 \mathrm{mV}$, $\tau=229 \mathrm{~ms}, N=24$; the time constants in Fig. $3 B$ lack error bars because they are from single exponential fits to averaged capacitance traces).

We also found no effect on the time constant of endocytosis when we varied the duration of depolarizing steps ( -70 to $-10 \mathrm{mV}$ ) from 5 to $100 \mathrm{~ms}$. Because of the fast kinetics of RRP exocytosis from cones $\left(\tau_{\text {exocytosis }} \approx 3 \mathrm{~ms}\right.$, Rabl et al., 2005; Fig. $3 E$, below), little additional membrane was added with steps longer than $5 \mathrm{~ms}$, up to $100 \mathrm{~ms}$ (Rabl et al., 2005). Thus, near 
the peak of the calcium current, lengthening the depolarizing steps primarily had the effect of increasing calcium influx rather than triggering additional vesicle fusion. Changing the step duration did increase the amount of membrane retrieved, with longer steps favoring excess endocytosis (Artalejo et al., 1995, 1996; Wu et al., 2009; Renden and von Gersdorff, 2007). The amount of membrane that was retrieved increased from $99 \pm 11 \%$ for a $5 \mathrm{~ms}$ step to $117 \pm$ $11 \%$ for a $100 \mathrm{~ms}$ step (Fig. 3C). The net result of this increase in the total amount of membrane retrieval was that, even though the time constant did not change, the rate of endocytosis was enhanced with longer step durations ( $5 \mathrm{~ms}, 523 \pm 55 \mathrm{fF} / \mathrm{s}$, $N=12 ; 10 \mathrm{~ms}, 502 \pm 64 \mathrm{fF} / \mathrm{s}, N=7 ; 15$ $\mathrm{ms}, 481 \pm 74 \mathrm{fF} / \mathrm{s} N=10 ; 20 \mathrm{~ms}, 581 \pm 78$ $\mathrm{fF} / \mathrm{s}, N=7 ; 25 \mathrm{~ms}, 621 \pm 70 \mathrm{fF} / \mathrm{s}, N=29$; $50 \mathrm{~ms}, 697 \pm 92 \mathrm{fF} / \mathrm{s}, N=9 ; 100 \mathrm{~ms}$, $816 \pm 123 \mathrm{fF} / \mathrm{s}, N=12$ ).

We also performed experiments in which we included a high concentration of the fast calcium chelator BAPTA (10 $\mathrm{mM}$ ) in the pipette solution in place of EGTA. At hair cell ribbon synapses, high concentrations of intracellular BAPTA dramatically reduced the amount of exocytosis following depolarizing steps of all durations (Moser and Beutner, 2000; Johnson et al., 2008; Graydon et al., 2011). Using $10 \mathrm{~mm}$ BAPTA in the cone pipette solution enabled us to acutely reduce the amount of exocytosis in cones and monitor whether endocytosis was affected. To do this, we recorded a capacitance response shortly after rupturing the patch and again several minutes later, after BAPTA had a chance to diffuse into the cell (Fig. 3D). Similar to hair cells, the presence of a high concentration of BAPTA dramatically reduced the amount of exocytosis at all step durations tested (Fig. $3 E$ ). In control conditions, the increase in exocytotic capacitance change as a function of test step duration could be well fit with two exponentials ( $\tau_{\text {fast }}=4.8$ $\left.\mathrm{ms}, \tau_{\text {slow }}=887 \mathrm{~ms}\right)$. With $10 \mathrm{~mm}$ BAPTA in the pipette, however, the data were well fit by only a single exponential function with $\tau=7.7 \mathrm{~ms}$. Despite the dramatic reduction of exocytosis by the inclusion of $10 \mathrm{~mm}$ BAPTA, this manipulation had no effect on the time constant of endocytosis across all stimulus durations we tested $(5 \mathrm{~ms}, \tau=233 \pm 33 \mathrm{~ms}$, $N=5 ; 10 \mathrm{~ms}, \tau=240 \pm 38 \mathrm{~ms}, N=9 ; 15 \mathrm{~ms}, \tau=280 \pm 50 \mathrm{~ms}$, $N=11 ; 25 \mathrm{~ms}, \tau=203 \pm 15 \mathrm{~ms}, N=14 ; 50 \mathrm{~ms}, \tau=206 \pm 39 \mathrm{~ms}$, $N=4 ; p>0.05$ for all step durations; Fig. $3 F$ ). BAPTA (10 mM) did reduce the amount of excess endocytosis following longer depolarizing steps; after a $25 \mathrm{~ms}$ step, the amount of retrieved membrane was reduced to $103 \pm 4 \%$ of membrane added from exocytosis $(N=13$; $p=0.03$; compare with $\sim 117 \%$ with $5 \mathrm{mM}$ EGTA, above). The findings above contrast with observations of slow endocytosis at the hair cell ribbon synapse $(\tau>5 \mathrm{~s})$ where
B

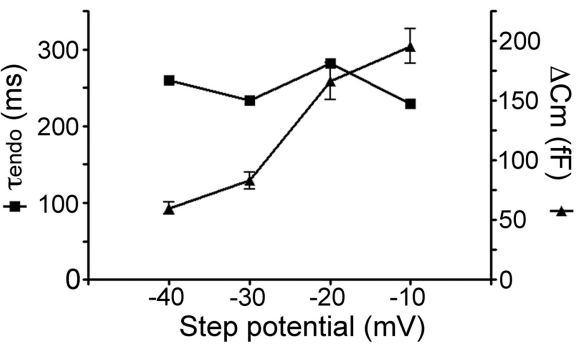

D $10 \mathrm{mM}$ BAPTA

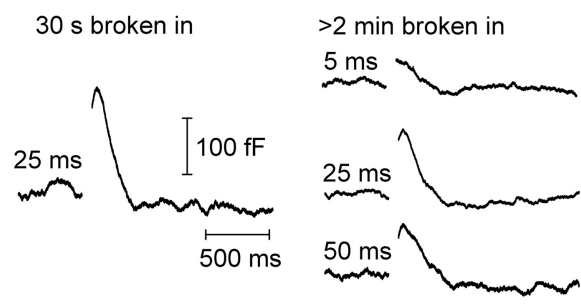

$\mathbf{F}$

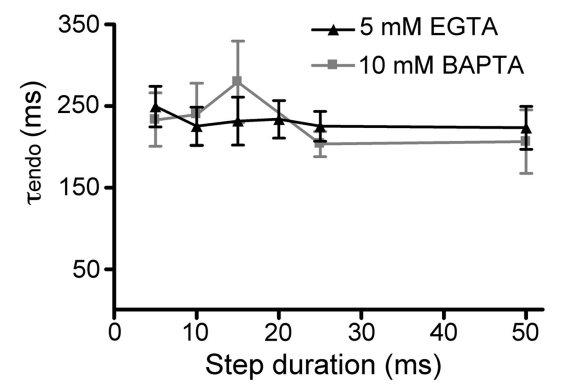

Figure 3. Time constant of endocytosis is unaffected by endocytic load. Whole-cell recordings from cones in salamander retinal slice. A, Averaged capacitance recordings in response to steps to $-10 \mathrm{mV}(\mathrm{N}=24),-20 \mathrm{mV}(\mathrm{N}=23),-30 \mathrm{mV}(\mathrm{N}=23)$, and constant of endocytosis. $\boldsymbol{B}$, Summary data showing the time constants of endocytosis (left axis, squares) and the capacitance in response to step depolarizations of varying amplitude (right axis, triangles). The time constants are from fits to the ce at each step potential and therefore have no error bars. C, Increasing step duration enhanced retrieval by exces endocytosis. The values were $99 \pm 11 \%$ of exocytosed membrane recovered $800 \mathrm{~ms}$ after the end of a $5 \mathrm{~ms}$ step, $98 \pm 4 \%$ for a 10 列 mM BAPTA. The trace on the left was recorded within $30 \mathrm{~s}$ of rupturing the patch, while those on the right were recorded after $>$ with control conditions ( $5 \mathrm{~mm}$ EGTA), $10 \mathrm{~mm}$ BAPTA reduced the exocytotic capacitance response of cones at all step durations. The exocytotic capacitance responses in control conditions were fit with two exponential functions $\left(\tau_{\text {fast }}=4.8 \mathrm{~ms}, \tau_{\text {slow }}=887 \mathrm{~ms}\right.$ ) while the responses in $10 \mathrm{~mm}$ BAPTA were fit with only a single exponential $(\tau=7.7 \mathrm{~ms}) . \boldsymbol{F}$, Compared with control conditions (5 $\mathrm{mm}$ EGTA), the time constant of endocytosis was unaffected by the presence of $10 \mathrm{~mm}$ BAPTA.

the kinetics slowed with increasing exocytosis, possibly due to saturation of endocytic capacity (Cho et al., 2011). The lack of an effect of increased exocytosis on the time constant of ultrafast endocytosis in cones, at least over the range of stimuli used here, is consistent with the presence of a high-capacity mechanism of endocytosis that is capable of keeping up with high rates of vesicle fusion.

We next sought to manipulate calcium within the terminal by using a lower concentration of either EGTA $(0.5 \mathrm{~mm})$ or BAPTA ( $1 \mathrm{~mm}$; Fig. 4). Unlike $10 \mathrm{~mm}$ BAPTA, $1 \mathrm{~mm}$ BAPTA has minimal effects on the amount of exocytosis (Babai et al., 2010; Mercer et al., 2011). The time constant of endocytosis following a $25 \mathrm{~ms}$ depolarization was not significantly different from the $5 \mathrm{~mm}$ EGTA controls whether we used 0.5 mM EGTA (Fig. $4 A, B ; \tau=$ 
A $0.5 \mathrm{mM}$ EGTA

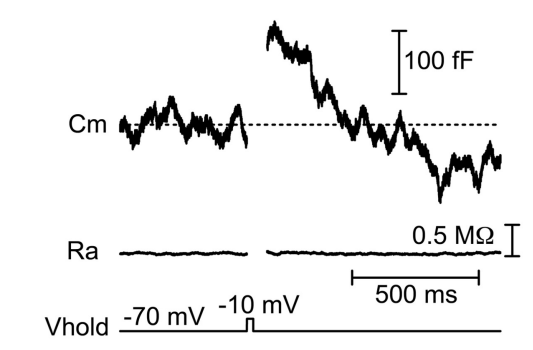

C 1 mM BAPTA
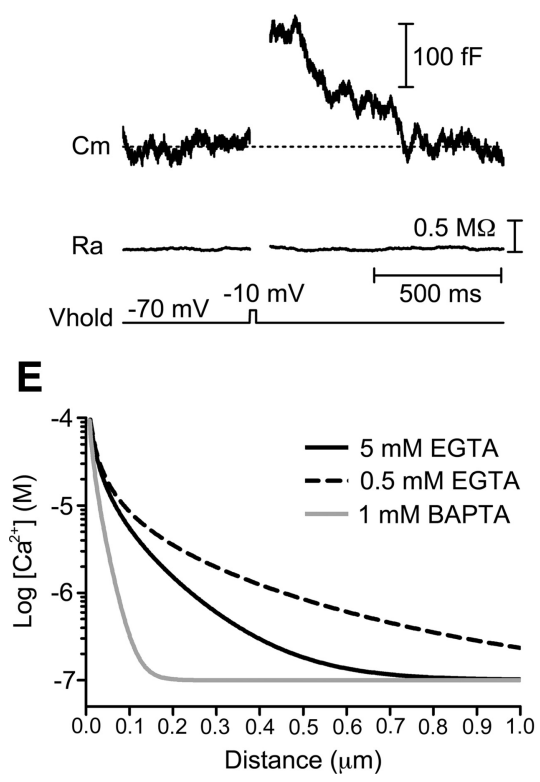

B $0.5 \mathrm{mM}$ EGTA

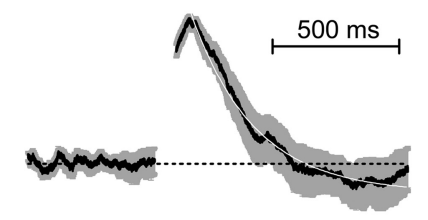

D 1 mM BAPTA

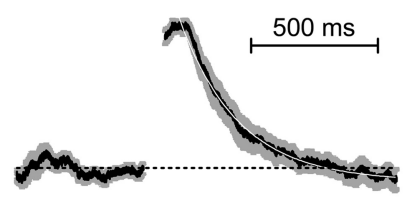

$\mathbf{F}$

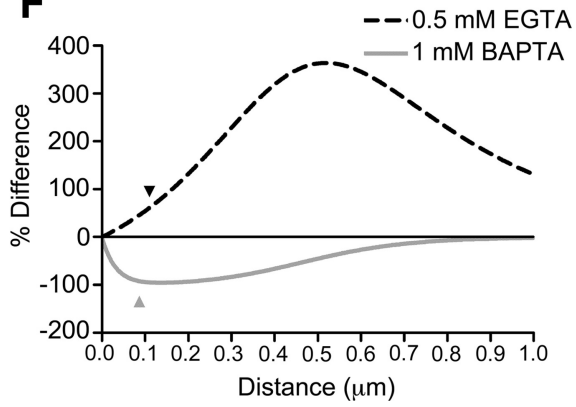

BAPTA conditions and plotted these differences as a percentage of the calcium levels predicted for 5 mM EGTA (Fig. 4F). With $1 \mathrm{~mm}$ BAPTA, submembrane calcium levels declined to $92 \%$ of levels predicted for 5 mM EGTA at a distance of 87 $\mathrm{nm}$ from the channel. Similarly, with 0.5 mM EGTA, calcium levels were predicted to be $62 \%$ more than $5 \mathrm{~mm}$ EGTA at a distance of $110 \mathrm{~nm}$. Thus, if one assumes a linear relationship between calcium and excess endocytosis, then both buffer conditions suggest that the triggering of excess endocytosis involves sites $\sim 100 \mathrm{~nm}$ from calcium channels responsible for triggering exocytosis. In addition to the assumption of linearity, this analysis assumes that the chelator concentration at the ribbon matched that in the pipette solution and so these values should be taken as lower bound estimates.

Finally, we also measured capacitance responses after elevating the concentration of $\mathrm{Ca}^{2+}$ in the extracellular medium $\left(\left[\mathrm{Ca}^{2+}\right]_{\mathrm{o}}\right)$ from 1.8 to $5 \mathrm{~mm}$ to enhance $\mathrm{Ca}^{2+}$ influx during a step depolarization (Fig. 5). Although this manipulation increased the $\mathrm{Ca}^{2+}$ charge transfer $\left(Q_{\mathrm{Ca}}\right)$ more than threefold $(2.9 \pm 0.4 \mathrm{pC}$ in $5 \mathrm{~mm}$ $\mathrm{Ca}^{2+}, N=14$; vs $0.78 \pm 0.1 \mathrm{pC}$ in $1.8 \mathrm{~mm}$ $\mathrm{Ca}^{2+}, N=15 ; p=0.00022$; Fig. $5 A$ ), it had no effect on the time constant of endocytosis $(\tau=281 \pm 29 \mathrm{~ms}$ in $1.8 \mathrm{~mm}$ $\mathrm{Ca}^{2+}, N=15 ; 297 \pm 32 \mathrm{~ms}$ in $5 \mathrm{mM} \mathrm{Ca}^{2+}$, $N=19 ; p=0.7$; Fig. $5 B$ ). Increasing $\left[\mathrm{Ca}^{2+}\right]_{0}$ to $5 \mathrm{~mm}$ slightly favored excess endocytosis. At $800 \mathrm{~ms}$ following a $25 \mathrm{~ms}$ step, $147 \pm 11 \%(N=20)$ of exocytosed membrane was recovered. These values are greater than those observed in $1.8 \mathrm{~mm}$ $\mathrm{Ca}^{2+}(116 \pm 6 \% ; N=15 ; p=0.02)$. Across both 1.8 and $5.0 \mathrm{mM} \mathrm{Ca}^{2+}$ conditions, the percentage of membrane retrieved by endocytosis was positively correlated with $Q_{\mathrm{Ca}}\left(r^{2}=0.34 ; p<0.005\right.$; Pearson correlation; Fig. 5C). The result of this increase in excess endocytosis is that the rate of membrane retrieval was slightly enhanced with greater calcium in-

$241 \pm 17 \mathrm{~ms} ; N=17 ; p=0.51$ ) or $1 \mathrm{~mm}$ BAPTA (Fig. $4 C, D ; \tau=$ $287 \pm 48 \mathrm{~ms} ; N=19 ; p=0.26$ ). However, $0.5 \mathrm{~mm}$ EGTA did favor excess endocytosis (Fig. 4B). With 0.5 mm EGTA in the pipette, the total amount of recovery at $800 \mathrm{~ms}$ after the depolarizing step (127 $\pm 7 \%$ of release) was greater than with $1 \mathrm{~mm}$ BAPTA $(101 \pm 6 \%, p=0.0092)$. Thus, $1 \mathrm{~mm} \mathrm{BAPTA}$ caused $92 \%$ suppression while $0.5 \mathrm{~mm}$ EGTA caused $61 \%$ enhancement of excess endocytosis relative to $5 \mathrm{~mm}$ EGTA conditions.

To estimate the distance of mechanisms that trigger excess endocytosis in cones, we used a model to predict the profiles of calcium diffusion around an open channel under the different buffering conditions (Fig. 4E; Ward and Kenyon, 2000; Mercer et al., 2011). From this model, we then calculated the differences in calcium profiles between $5 \mathrm{~mm}$ EGTA and $0.5 \mathrm{~mm}$ EGTA or $1 \mathrm{~mm}$ flux $\left(371 \pm 30 \mathrm{fF} / \mathrm{s}\right.$ in $1.8 \mathrm{mM} \mathrm{Ca}^{2+}$ vs $490 \pm 41 \mathrm{fF} / \mathrm{s}$ in $5 \mathrm{~mm}$ $\left.\mathrm{Ca}^{2+} ; p=0.025\right)$.

\section{Dynamin}

Most forms of endocytosis appear to rely on the GTPase dynamin for fission of endocytosed synaptic vesicles (Royle and Lagnado, 2003, 2010; Dittman and Ryan, 2009). We therefore undertook a series of experiments to test whether dynamin plays a role in fast endocytosis in cones (Fig. 6). We first used the membranepermeant small molecule inhibitor of dynamin, dynasore (Macia et al., 2006; Newton et al., 2006). However, endocytosis was not blocked and its time course was not significantly different from control conditions (Fig. 1) when we included dynasore in the superfusate (Fig. $6 A ; 80 \mu \mathrm{M} ; \tau=232 \pm 34 \mathrm{~ms}, N=9, p=0.87$ ) or 

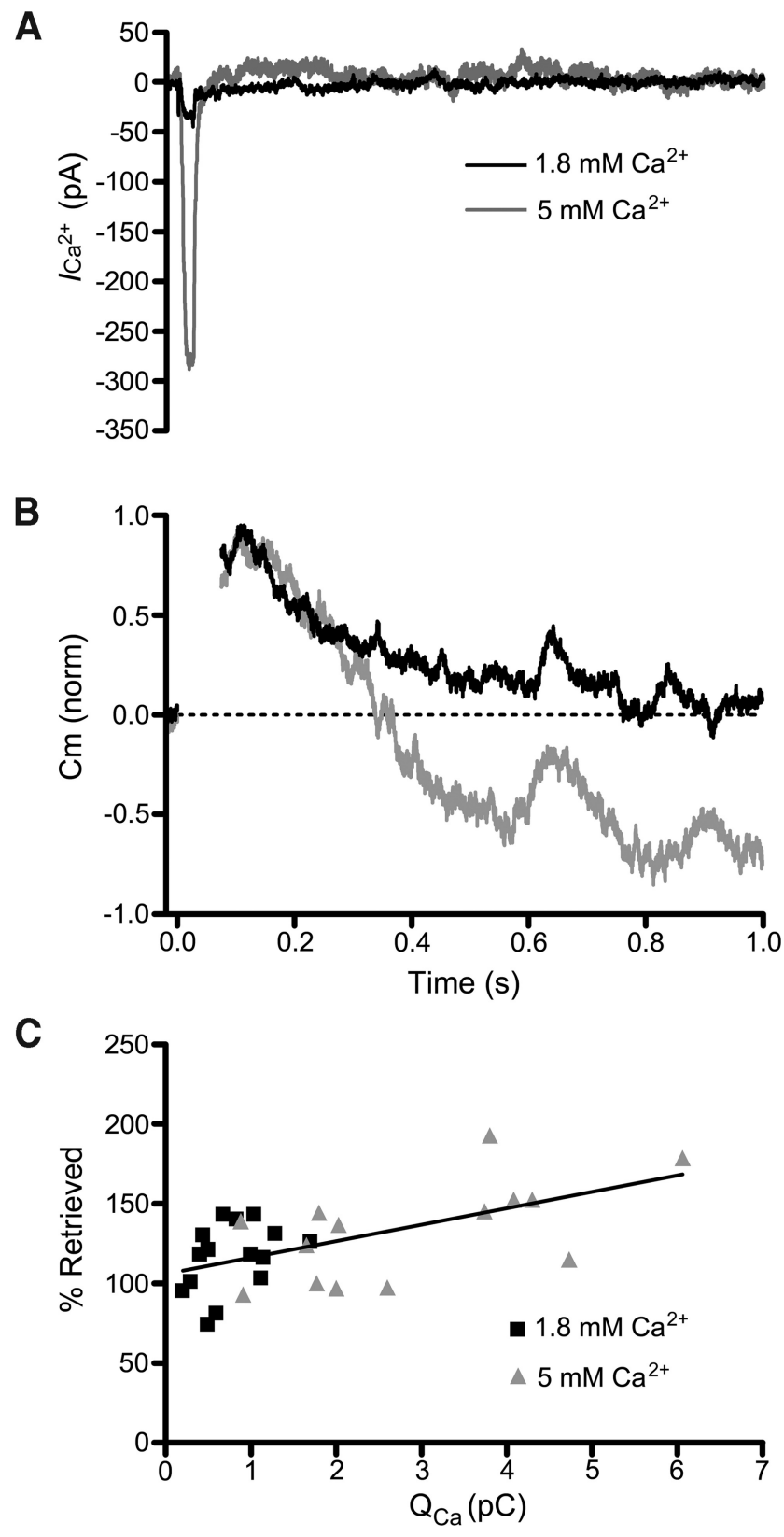

Figure 5. Calcium influx enhances endocytosis overshoot. Whole-cell recordings in which extracellular $\left[\mathrm{Ca}^{2+}\right]$ was varied. $A$, Leak-subtracted calcium currents from two different cones recorded in response to a depolarizing step $(-70 \mathrm{mV}$ to $-10 \mathrm{mV}, 25 \mathrm{~ms})$ in the presence of 1.8 $\mathrm{mm} \mathrm{Ca}^{2+}$ (black) and $5 \mathrm{~mm} \mathrm{Ca}^{2+}$ (gray). B, Normalized capacitance responses of the same two cells in response to the step depolarizations. In the presence of $5 \mathrm{~mm}$ extracellular $\mathrm{Ca}^{2+}$ (gray), the capacitance trace overshot the baseline. $C$, Calcium charge transfer $\left(Q_{C_{a}}\right)$ and membrane retrieval for 1.8 and $5.0 \mathrm{~mm} \mathrm{Ca}^{2+}$ conditions. There is a positive correlation $\left(r^{2}=0.34 ; p<\right.$ 0.005 ; Pearson correlation) of the amount of membrane retrieval with the $Q_{\mathrm{ca}}$.

introduced it into cones through the patch pipette (Fig. $6 B ; 80$ $\mu \mathrm{M} ; \tau=253 \pm 60 \mathrm{~ms}, N=10, p=0.67)$. Dynasore also had no effect on excess endocytosis whether it was bath applied or introduced via the pipette $(122 \pm 10 \%$ recovered, $p=0.62$ and $104 \pm$ $9 \%$ recovered, $p=0.23$, respectively). Likewise, when we introduced another small molecule dynamin inhibitor, Dyngo (Fig. $6 C ; 30 \mu \mathrm{M}$; Harper et al., 2011), through the patch pipette, neither the time constant $(\tau=287 \pm 38 \mathrm{~ms} ; N=6)$ nor the amount of endocytosis ( $105 \pm 4 \%$ retrieved; $N=6)$ differed significantly from controls $(p=0.2, p=0.08$, respectively). We next replaced
GTP in the patch pipette with a nonhydrolyzable analog, GTP $\gamma \mathrm{S}$ (4 mM). This also had no effect on the kinetics (Fig. $6 D ; \tau=242 \pm$ $39 \mathrm{~ms}, N=7, p=0.7)$ or extent of endocytosis $(114 \pm 7 \%$ recovered, $p=0.8$ ). When we dialyzed cones with a peptide that blocks some forms of clathrin-mediated endocytosis by disrupting interactions of dynamin with amphiphysin (Grabs et al., 1997; Shupliakov et al., 1997; Jockusch et al., 2005; Yamashita et al., 2005), the endocytosis kinetics was also unchanged from control (Fig. $6 E ; \tau=265 \pm 37 \mathrm{~ms}, N=14, p=0.36$ ), as was the amount of retrieved membrane $(116 \pm 7 \%$ recovered, $p=0.69)$. Together with the fast kinetics of cone endocytosis, which is faster than estimates of clathrin-mediated endocytosis (Jockusch et al., 2005; Wu et al., 2007; Royle and Lagnado, 2010), this suggests that clathrin is not involved in this rapid form of synaptic vesicle retrieval in cones. The absence of any effect of dynamin blockers suggests that dynamin is also not involved.

Because ATP hydrolysis has been implicated in regulating fast endocytosis at the goldfish Mb1 bipolar cell ribbon synapse in a GTP-independent mechanism (Heidelberger, 2001; Jockusch et al., 2005), we also tested whether ATP might play a similar role at the cone ribbon synapse. In control conditions, the exocytotic capacitance responses slowly ran down over the course of our recordings (Fig. $7 A-C$ ). Consistent with a role of ATP in vesicle replenishment at the cone and bipolar cell synapse (Heidelberger et al., 2002; Linton et al., 2010), rundown was quickened when we replaced the ATP in the pipette solution with the nonhydrolyzable analog, ATP $\gamma \mathrm{S}(9.4 \mathrm{~mm}$; Fig. $7 \mathrm{~B}, \mathrm{C})$. Rundown in these experiments followed time courses similar to rundown in paired cone-horizontal cell recordings with and without ATP (Linton et al., 2010; Bartoletti and Thoreson, 2011), providing additional evidence that capacitance changes represent genuine exocytosis and endocytosis. Along with the ability of BAPTA to rapidly inhibit release, the observed effect of ATP $\gamma \mathrm{S}$ on rundown also serves as a positive control that substances introduced through the patch pipette can diffuse to the cone terminal and exert an effect at the ribbon. However, ATP $\gamma \mathrm{S}$ had no effect on kinetics $(\tau=248 \pm 37 \mathrm{~ms}, N=8, p=0.6)$ or extent $(112 \pm 5 \%$ recovered $p=0.42$ ) of endocytosis (Fig. 7D).

Previous studies have shown that fast endocytosis at the goldfish bipolar cell synapse is inhibited by elevation of intracellular chloride (Hull and von Gersdorff, 2004). However, a nearly fourfold increase in intracellular chloride (from 17.5 to $67.5 \mathrm{~mm}$ ), similar to the concentration that inhibited bipolar cell endocytosis, had no significant effect on either the time constant $(\tau=$ $272 \pm 30 \mathrm{~ms} ; N=8 ; p=0.21)$ or extent of endocytosis $(106 \pm 5 \%$ recovery at $800 \mathrm{~ms}$ after the step; $N=8 ; p=0.19$ ) in cones.

\section{Endocytosis in rods}

Previous studies have suggested that endocytosis in rods is slower than in cones (Rabl et al., 2005; Rieke and Schwartz, 1996) and there may be differences among endocytic proteins in rod and cone terminals (Van Epps et al., 2004; Sherry and Heidelberger, 2005; Holzhausen et al., 2009), raising the possibility that endocytosis proceeds by different mechanisms in rods and cones. In control conditions, we found that endocytosis was slower in rods, exhibiting a time constant of $416 \pm 91 \mathrm{~ms}$ following a $50 \mathrm{~ms}$ step depolarization. Rods also showed little excess endocytosis. By $1200 \mathrm{~ms}$ after the depolarizing step, rods recovered $103 \pm 8 \%$ of the membrane from exocytosis $(N=14)$. Additionally, although fast endocytosis in cones was insensitive to the dynamin inhibitor dynasore, this compound inhibited endocytosis in rods (Fig. 8B). In the presence of dynasore ( $80 \mu \mathrm{M}$, bath-applied), only $41 \pm$ $22 \%$ of the membrane was recovered $(N=8, p=0.026)$. When 
A

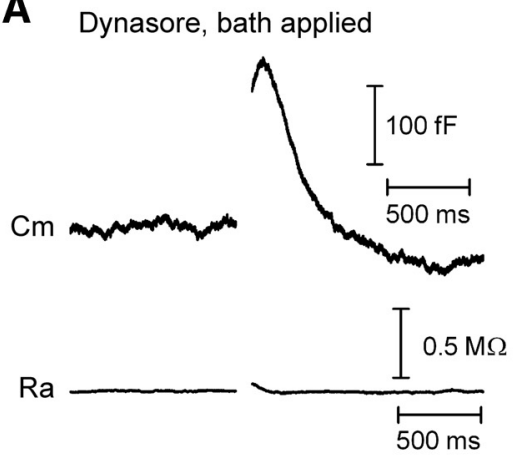

D

D GTPYS

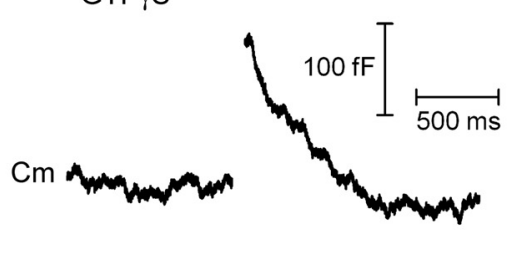

$\mathrm{Ra} \longrightarrow \frac{T_{500 \mathrm{~ms}}^{1}}{0.5 \mathrm{M} \Omega}$
B

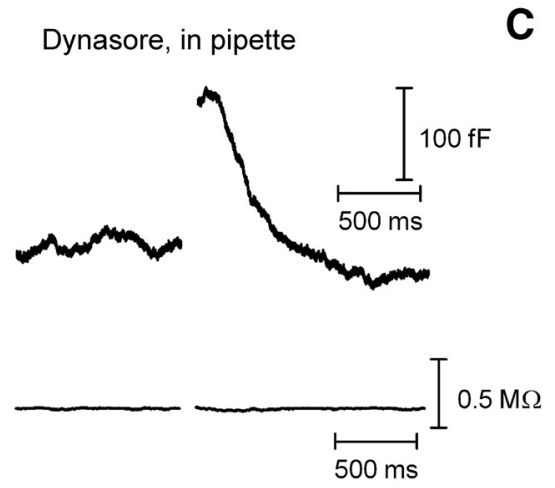

C

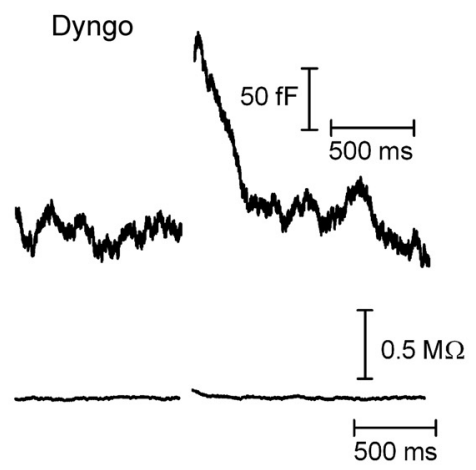

E

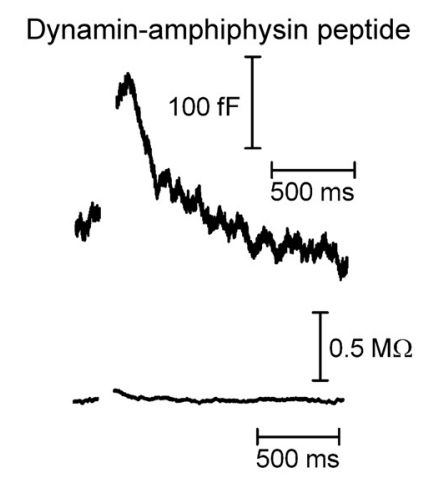

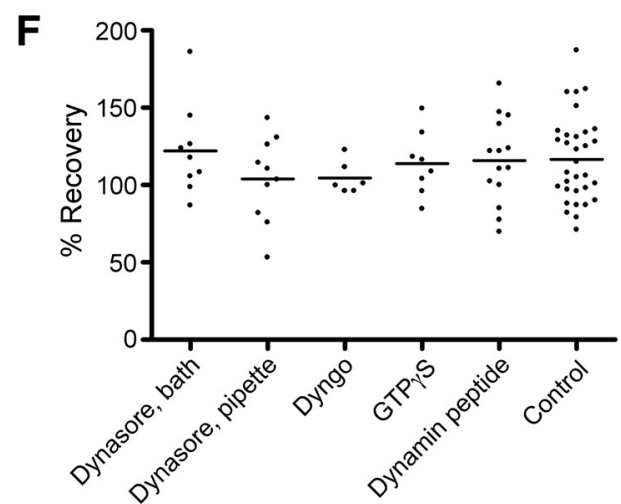

Figure 6. Dynamin inhibitors do not affect cone endocytosis. Whole-cell capacitance recordings from cones in response to depolarizing voltage steps $(-70$ to $-10 \mathrm{mV}, 25 \mathrm{~ms})$. Each trace is from a different cell and is an average of $2-10$ recordings. $A$, Example of a capacitance recording illustrating that bath-applied Dynasore $(80 \mu \mathrm{M})$ did not affect endocytosis. Baseline values: $C_{\mathrm{m}}=39.4$ $\mathrm{pF}, \mathrm{Ra}=39.5 \mathrm{M} \Omega . \boldsymbol{B}$, Inclusion of Dynasore $(80 \mu \mathrm{M})$ in the pipette solution also had no effect on endocytosis. Baseline values: $C_{\mathrm{m}}=54.1 \mathrm{pF}, \mathrm{Ra}=38.5 \mathrm{M} \Omega$. $C$, Inclusion of Dyngo $(30 \mu \mathrm{M})$, another small-molecule inhibitor of dynamin, in the patch pipette also had no effect on endocytosis. Baseline values: $C_{m}=34.7 \mathrm{pF}, \mathrm{Ra}=36.3 \mathrm{M} \Omega$. D, Including the nonhydrolyzable GTP analog GTP $\gamma S$ (4 $\mathrm{mm}$ ) in the pipette solution in place of GTP also had no effect on endocytosis. Baseline values: $C_{\mathrm{m}}=42.2 \mathrm{pF}$, Ra $=32.3 \mathrm{M} \Omega$. $E$, The dynamin-amphiphysin peptide disrupts dynamin-dependent clathrin-mediated endocytosis. However, when included in the pipette solution $(750 \mu \mathrm{m})$, endocytosis was not different from control conditions. Baseline values: $C_{\mathrm{m}}=33.5 \mathrm{pF}, \mathrm{Ra}=45.9 \mathrm{M} \Omega . \boldsymbol{F}$, Group data showing that the amount of membrane retrieval was unchanged in all conditions when compared with control recordings $(p>0.05)$. Vhold, holding potential; $C_{m}$, membrane capacitance; $R a$, access resistance.

GTP in the pipette solution was replaced with $4 \mathrm{~mm} \mathrm{GTP} \gamma \mathrm{S}$, rods recovered only $53 \pm 11 \%$ of the membrane added during exocytosis (Fig. $8 C ; N=5 ; p=0.007$ ). Moreover, the amplitude of the exocytotic capacitance response was reduced from $144 \pm 11 \mathrm{fF}$ in control rods $(N=12)$ to $35 \pm 4 \mathrm{fF}$ in the presence of dynasore $(N=8 ; p<0.001)$ and $100 \pm 10 \mathrm{fF}$ when dialyzed with GTP $\gamma \mathrm{S}$ $(N=5 ; p<0.01)$, suggesting that rods may partially rely on endocytosis for resupply of vesicles for future release. In addition to showing that mechanisms of endocytosis differ in rods and cones, these results provide positive controls establishing the efficacy of dynasore and GTP $\gamma \mathrm{S}$ in inhibiting endocytosis in salamander photoreceptors. Unlike cone synapses, which rest at the base of the soma, rod terminals are connected to the cell body by a thin axon, which would be expected to slow diffusion of compounds introduced via the patch pipette. The ability of GTP $\gamma S$ to exert an effect on rods despite this potential obstacle suggests that it should easily reach a sufficient concentration to affect cone endocytosis if it relied on a GTP-dependent process.

\section{Discussion}

Using capacitance recording techniques, we found that endocytosis in cone photoreceptors involves a very fast component of membrane retrieval, with a time constant of $\sim 250 \mathrm{~ms}$. This is consistent with earlier measurements of endocytosis in salamander photoreceptors suggesting a fast component with a time constant $<1$ s (Rieke and Schwartz, 1996; Rabl et al.,
2005; Snellman et al., 2011; Mercer et al., 2012). Although calcium did not affect the time constant, greater calcium influx appeared to quicken the rate by enhancing excess retrieval. Endocytosis was unaffected by inhibitors of dynamin function, suggesting that dynamin plays little, if any, role in this fast form of endocytosis.

Two kinetically and mechanistically distinct modes of endocytosis - fast ( $\tau=1-2 \mathrm{~s}$ ) and slow $(\tau=10-20 \mathrm{~s})$ - have been characterized by capacitance techniques in retinal bipolar cell terminals and the calyx of Held (von Gersdorff and Matthews, 1994a; Neves and Lagnado, 1999; Sun and Wu, 2001; Jockusch et al., 2005; Wu et al., 2005). The fast endocytosis we observed in cones $(\tau \approx 250 \mathrm{~ms})$ is considerably faster than in either bipolar cells or at the calyx of Held and may therefore constitute another distinct, "ultrafast" mechanism. An ultrafast form of endocytosis with $\tau \approx 300 \mathrm{~ms}$ has been reported at the ribbon synapse of inner hair cells (Beutner et al., 2001) and in chromaffin and pituitary cells ( $\tau=300-350$ ms; Thomas et al., 1994; Artalejo et al., 1995; Hsu and Jackson, 1996) and appears to be mechanistically distinct from fast $(\tau=1-2 \mathrm{~s})$ or slow $(\tau=10-20 \mathrm{~s})$ modes at the same synapses (Artalejo et al., 1995; Hsu and Jackson, 1996; Moser and Beutner, 2000; Beutner et al., 2001). Ultrafast endocytosis ( $\tau=400-900 \mathrm{~ms}$ ) has also been observed using the $\mathrm{pH}$ sensor synaptopHluorin in hippocampal neurons (Gandhi and Stevens, 2003). The molecular mechanisms underlying ultrafast 
endocytosis are unclear, although some have suggested that it represents the initiation of a late step in a two-part pathway already primed for retrieval (Thomas et al., 1994).

It is likely that slower modes of endocytosis are also involved in vesicle retrieval in cones, but activated under different conditions than the ultrafast mode described here. Because of prominent $\mathrm{Ca}^{2+}$-activated tail currents evoked by long steps, we did not use depolarizing steps that exceeded $100 \mathrm{~ms}$. In isolated salamander cones, Innocenti and Heidelberger (2008) found that following stimulation with long depolarizing steps (0.5-5 s), membrane was retrieved very slowly, over tens of seconds. This may be the result of recruitment of slower endocytic pathways following saturation of a fast mode of endocytosis or increases in intraterminal calcium and/or recruitment of calmodulin-triggered mechanisms of endocytosis during sustained depolarization (Wu, 2004; Wu et al., 2009). Alternatively, slower forms of endocytosis may require intracellular signaling molecules that can be lost during ruptured patch whole-cell recording (Parsons et al., 1994; Cho et al., 2011).

Ultrafast cone endocytosis is unlikely to involve a clathrin-dependent pathway. It is faster than most estimates of clathrinmediated synaptic vesicle endocytosis (Jockusch et al., 2005; Wu et al., 2007; Royle and Lagnado, 2010) and was unaffected by dialyzing cones with the dynamin-amphiphysin peptide. However, clathrin may contribute to slower components of endocytosis since photoreceptor terminals contain clathrin and clathrin-coated vesicles (Gray and Pease, 1971; Sherry and Heidelberger, 2005; Zampighi et al., 2011) and tracer uptake studies have shown that multiple mechanisms of endocytosis, including retrieval of both coated and uncoated vesicles, are involved in cone terminals (Ripps et al., 1976; Schacher et al., 1976; Schaeffer and Raviola, 1978; Cooper and McLaughlin, 1983; Rea et al., 2004).

While it does not appear to require clathrin, ultrafast endocytosis in some systems has been shown to depend on dynamin and GTP hydrolysis (Artalejo et al., 1995). Dynamin is a mechanoenzyme GTPase thought to be essential in the last stages of endocytosis, where it constricts the neck of a budding vesicle, pinching it off from the plasma membrane (Sweitzer and Hinshaw, 1998; Marks et al., 2001; Roux et al., 2006). Surprisingly, we were unable to block endocytosis in cones with compounds that inhibit dynamin or GTP
A
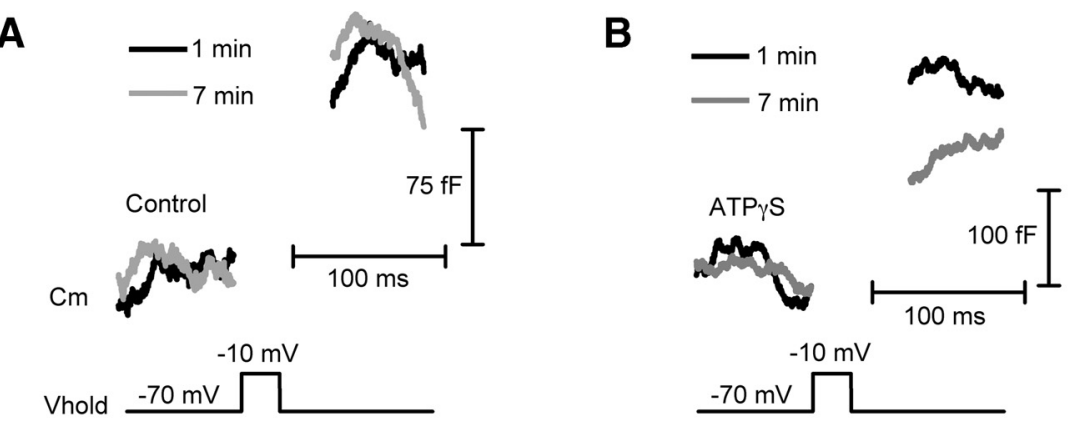

C
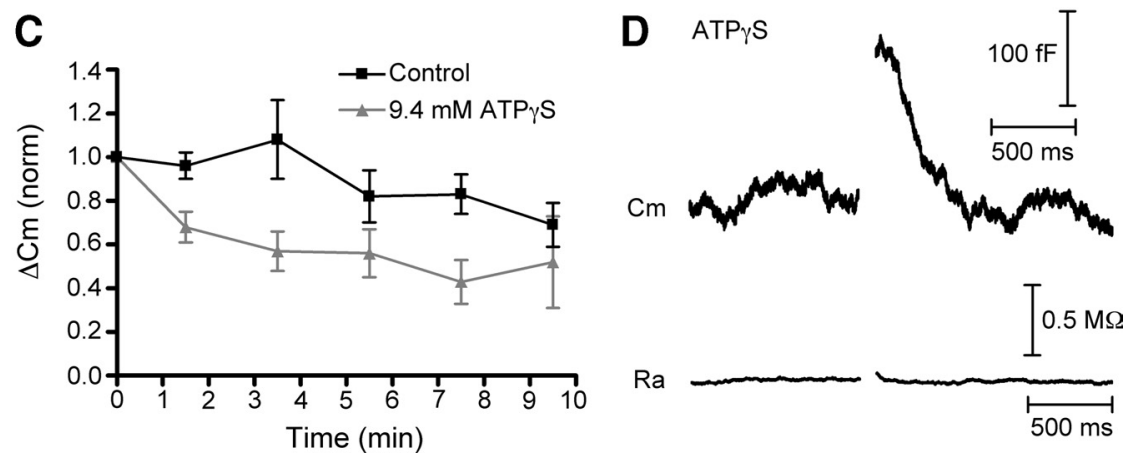

Figure 7. Cone endocytosis does not depend on ATP.A-C, Rundown of exocytosis is accelerated by ATP $\gamma$ S. $\boldsymbol{A}$, Capacitance recordings from $1 \mathrm{~min}$ (black) and $7 \mathrm{~min}$ (gray) after establishing whole-cell recording in control conditions (with $9.4 \mathrm{mM}$ ATP included in the pipette solution) in response to $25 \mathrm{~ms}$ depolarizing steps to $-10 \mathrm{mV}$ from a holding potential of $-70 \mathrm{mV}$. $\boldsymbol{B}$, Capacitance recordings as in $\boldsymbol{A}$, except that the ATP in the pipette solution had been replaced with $9.4 \mathrm{~mm} \mathrm{ATP} \gamma$ S.C. Amplitude of capacitance responses to 25 ms depolarizations normalized to the first response (time $=0$ ) and binned every $2 \mathrm{~min}$. Although the exocytotic capacitance response ran down over the 10 min of recording in control conditions (black), rundown was accelerated when ATP was replaced with ATP $\gamma S$ (gray). D, Average of three capacitance responses from a single cell showing that ATP $\gamma$ S had no effect on fast endocytosis. Baseline values: $C_{\mathrm{m}}=37.1 \mathrm{pF}, \mathrm{Ra}=38.3$ $M \Omega$. Vhold, holding potential; $C_{m}$, membrane capacitance; $R a$, access resistance.
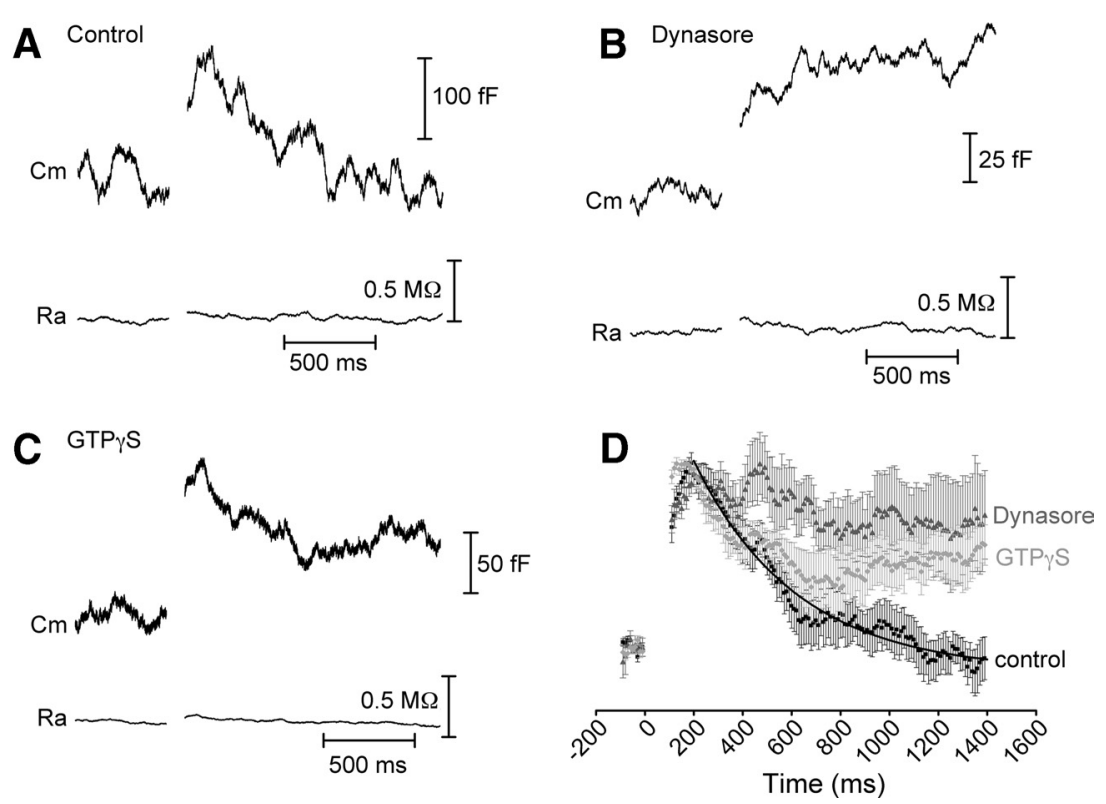

Figure 8. Rod endocytosis involves dynamin and GTP hydrolysis. Whole-cell capacitance recordings from rod photoreceptors in salamander retinal slice. $\boldsymbol{A}$, Example capacitance trace in response to a $50 \mathrm{~ms}$ step in control conditions. The decline of the capacitance signal back to baseline could be fit with a single exponential with $\tau=495 \mathrm{~ms}$ (data not shown). Baseline values: $C_{m}=27.7 \mathrm{pF}, \mathrm{Ra}=39.6 \mathrm{M} \Omega$. $\boldsymbol{B}$, Example capacitance trace in response to a $50 \mathrm{~ms}$ step showing that rod endocytosis was inhibited when retinal slices were treated with the small molecule dynamin inhibitor Dynasore $(80 \mu \mathrm{m})$. Baseline values: $C_{\mathrm{m}}=34.2 \mathrm{pF}$, Ra $=35.2 \mathrm{M} \Omega$. C, Example capacitance trace when $4 \mathrm{~mm}$ GTP $\gamma S$ was included in the patch pipette, showing that GTP $\gamma S$ partially inhibited membrane retrieval. Baseline values: $C_{\mathrm{m}}=$ $21.1 \mathrm{pF}, \mathrm{Ra}=40.1 \mathrm{M} \Omega . D$, Average and SEM normalized capacitance recordings recorded in response to a $50 \mathrm{~ms}$ step in control conditions (black, $N=14$ ), in the presence of dynasore ( $80 \mu \mathrm{m}$, dark gray, $N=8)$, or in the presence of GTP $\gamma S(30 \mu \mathrm{m}$, light gray, $N=5)$. The control trace was fit with a single exponential function $(\tau=420 \mathrm{~ms})$. $C_{\mathrm{m}}$, membrane capacitance; $R a$, access resistance. 
hydrolysis, although they were effective at inhibiting endocytosis in rods. Immunohistochemical analysis has shown that dynamin is present at ribbon synapses in rod and cone terminals in both fish and rodent (Ullrich and Südhof, 1994; Sherry and Heidelberger, 2005), although the labeling is weaker and more diffuse than in conventional synapses (Sherry and Heidelberger, 2005). Heidelberger (2001) showed that fast endocytosis in goldfish bipolar cells depends on ATP hydrolysis rather than GTP (Jockusch et al., 2005). However, endocytosis in cones was unaffected by dialyzing the cell with the nonhydrolyzable ATP analog, ATP $\gamma$ S. Together, these data suggest that dynamin, GTP, and ATP play a lesser role in endocytosis at cone synapses.

Two previous studies have shown that synaptic vesicles can be retrieved following disruption of dynamin (Xu et al., 2008; Chung et al., 2010). In the hippocampus, dynamin-independent vesicles comprise a pool responsible for spontaneous release (Chung et al., 2010), while at the calyx of Held, they are released during intense stimulation (Xu et al., 2008). At present, little is known about the mechanisms able to catalyze membrane fission in place of dynamin- or GTP-dependent pathways.

One possibility is that the ribbon itself may have the necessary machinery to support dynamin-independent endocytosis. The major protein component of the synaptic ribbon, RIBEYE, is partially comprised of a CtBP/BARS domain (Schmitz et al., 2000) and a related CtBP3/BARS protein has been shown to play a role in membrane fission and transport independently of dynamin function (Bonazzi et al., 2005). The CtBP/BARS domain of RIBEYE may therefore be able to cleave budding vesicles independently of dynamin. In a previous study, however, endocytosis was unaffected following acute disruption of the ribbon (Snellman et al., 2011).

Calcium can play different roles in regulating endocytosis depending on which synapse and which endocytic mechanism is under study (Royle and Lagnado, 2003; Wu, 2004; Yamashita, 2012). In our experiments, the time constant of endocytosis was unchanged and no additional slow components were activated when we varied calcium chelators or altered calcium influx. However, calcium did facilitate excess endocytosis (Artalejo et al., 1996; Renden and von Gersdorff, 2007; Wu et al., 2009), which has the effect of increasing the overall rate of membrane retrieval. Experiments manipulating calcium buffering indicated that this involved sites $\sim 100 \mathrm{~nm}$ from calcium entry sites, only slightly farther than the estimated distance from calcium channels to release sites in cone terminals (Mercer et al., 2011). This suggests that the trigger for excess endocytosis is close to, or perhaps even a component of, the vesicle fusion machinery. Indeed, synaptotagmin, the calcium sensor for exocytosis, is able to bind endocytic proteins (Zhang et al., 1994; Chapman et al., 1998; Diril et al., 2006) and has been implicated as a calcium sensor for endocytosis (Wang et al., 2003; Yamashita, 2012; Yao et al., 2012a; b).

Is ultrafast endocytosis in cones evidence for kiss-and-run? Kiss-and-run is the partial fusion of a synaptic vesicle, release of its contents through a narrow pore, and rapid retrieval of membrane without full-collapse fusion ( $\mathrm{He}$ and $\mathrm{Wu}, 2007$ ). Electrophysiological and imaging evidence suggests that it may play a role in a variety of neuronal and neuroendocrine cells (Alés et al., 1999; Stevens and Williams, 2000; Klyachko and Jackson, 2002; Aravanis et al., 2003; Elhamdani et al., 2006; Harata et al., 2006; He et al., 2006; He and Wu, 2007). There is little evidence for kiss-and-run at ribbon synapses; in the goldfish bipolar cell terminal, vesicles clearly undergo full-collapse fusion (Zenisek et al., 2002) and a study monitoring endocytic uptake of styryl dyes suggests that kiss-and-run is not involved at cone terminals (Rea et al., 2004). Still, given that kiss-and-run endocytosis may result from reversal of a loose SNARE complex and therefore not require a classical endocytic pathway (Giraudo et al., 2005; Smith et al., 2008), the dynamin independence and ultrafast kinetics of endocytosis described in cones are potentially consistent with a kiss-and-run mechanism. However, kiss-and-run implies a total match of membrane added during exocytosis with the amount retrieved. Excess endocytosis in cones therefore argues against kiss-and-run being the sole endocytic mechanism. Direct evidence is needed for a more definitive demonstration.

In conclusion, we found that cones exhibit a component of synaptic vesicle endocytosis that is quite fast, providing a means for rapid retrieval of membrane following exocytosis. Much remains unknown about endocytosis in photoreceptors, including the differences in endocytic pathways between rods and cones. Previous work has pointed to involvement of synaptojanin in cones but not rods as being one such difference (Van Epps et al., 2004; Holzhausen et al., 2009). Our findings indicate that dependence on dynamin may be another. Additionally, clathrin is likely involved in slower forms of endocytosis in rods and cones (Gray and Pease, 1971; Schaeffer and Raviola, 1978; Zampighi et al., 2011), but conditions under which those pathways are activated remain to be elucidated.

\section{References}

Alés E, Tabares L, Poyato JM, Valero V, Lindau M, Alvarez de Toledo G (1999) High calcium concentrations shift the mode of exocytosis to the kiss-and-run mechanism. Nat Cell Biol 1:40-44. CrossRef Medline

Aravanis AM, Pyle JL, Tsien RW (2003) Single synaptic vesicles fusing transiently and successively without loss of identity. Nature 423:643-647. CrossRef Medline

Artalejo CR, Henley JR, McNiven MA, Palfrey HC (1995) Rapid endocytosis coupled to exocytosis in adrenal chromaffin cells involves $\mathrm{Ca}^{2+}$, GTP, and dynamin but not clathrin. Proc Natl Acad Sci U S A 92:8328-8332. CrossRef Medline

Artalejo CR, Elhamdani A, Palfrey HC (1996) Calmodulin is the divalent cation receptor for rapid endocytosis, but not exocytosis in adrenal chromaffin cells. Neuron 16:195-205. CrossRef Medline

Babai N, Bartoletti TM, Thoreson WB (2010) Calcium regulates vesicle replenishment at the cone ribbon synapse. J Neurosci 30:15866-15877. CrossRef Medline

Barnes S, Hille B (1989) Ionic channels of the inner segment of tiger salamander cone photoreceptors. J Gen Physiol 94:719-743. CrossRef Medline

Bartoletti TM, Thoreson WB (2011) Quantal amplitude at the cone ribbon synapse can be adjusted by changes in cytosolic glutamate. Mol Vis 17: 920-931. Medline

Bartoletti TM, Babai N, Thoreson WB (2010) Vesicle pool size at the salamander cone ribbon synapse. J Neurophysiol 103:419-423. CrossRef Medline

Beutner D, Voets T, Neher E, Moser T (2001) Calcium dependence of exocytosis and endocytosis at the cochlear inner hair cell afferent synapse. Neuron 29:681-690. CrossRef Medline

Bonazzi M, Spanò S, Turacchio G, Cericola C, Valente C, Colanzi A, Kweon HS, Hsu VW, Polishchuck EV, Polishchuck RS, Sallese M, Pulvirenti T, Corda D, Luini A (2005) CtBP3/BARS drives membrane fission in dynamin-independent transport pathways. Nat Cell Biol 7:570-580. CrossRef Medline

Chapman ER, Desai RC, Davis AF, Tornehl CK (1998) Delineation of the oligomerization, AP-2 binding, and synprint binding of the $\mathrm{C} 2 \mathrm{~B}$ domain of synaptotagmin. J Biol Chem 273:32966-32972. CrossRef Medline

Cho S, Li GL, von Gersdorff H (2011) Recovery from short-term depression and facilitation is ultrafast and $\mathrm{Ca}^{2+}$ dependent at auditory hair cell synapses. J Neurosci 31:5682-5692. CrossRef Medline

Chung C, Barylko B, Leitz J, Liu X, Kavalali ET (2010) Acute dynamin inhibition dissects synaptic vesicle recycling pathways that drive spontaneous and evoked neurotransmission. J Neurosci 30:1363-1376. CrossRef Medline 
Cooper NG, McLaughlin BJ (1983) Tracer uptake by photoreceptor synaptic terminals. I. Dark-mediated effects. J Ultrastruct Res 84:252-267. CrossRef Medline

Diril MK, Wienisch M, Jung N, Klingauf J, Haucke V (2006) Stonin 2 is an AP-2-dependent endocytic sorting adaptor for synaptotagmin internalization and recycling. Dev Cell 10:233-244. CrossRef Medline

Dittman J, Ryan TA (2009) Molecular circuitry of endocytosis at nerve terminals. Annu Rev Cell Dev Biol 25:133-160. CrossRef Medline

Elhamdani A, Azizi F, Artalejo CR (2006) Double patch clamp reveals that transient fusion (kiss-and-run) is a major mechanism of secretion in calf adrenal chromaffin cells: high calcium shifts the mechanism from kissand-run to complete fusion. J Neurosci 26:3030-3036. CrossRef Medline

Gandhi SP, Stevens CF (2003) Three modes of synaptic vesicular recycling revealed by single-vesicle imaging. Nature 423:607-613. CrossRef Medline

Gillis KD (2009) Techniques for membrane capacitance measurements. In: Single-channel recording, Ed 2 (Sakmann B, Neher E, eds), pp 155-198. New York: Springer.

Giraudo CG, Hu C, You D, Slovic AM, Mosharov EV, Sulzer D, Melia TJ, Rothman JE (2005) SNAREs can promote complete fusion and hemifusion as alternative outcomes. J Cell Biol 170:249-260. CrossRef Medline

Grabs D, Slepnev VI, Songyang Z, David C, Lynch M, Cantley LC, De Camilli P (1997) The SH3 domain of amphiphysin binds the proline-rich domain of dynamin at a single site that defines a new SHF binding consensus sequence. J Biol Chem 272:13419-13425. CrossRef Medline

Gray EG, Pease HL (1971) On understanding the organisation of the retinal receptor synapse. Brain Res 35:1-15. CrossRef Medline

Graydon CW, Cho S, Li GL, Kachar B, von Gersdorff H (2011) Sharp Ca ${ }^{2+}$ nanodomains beneath the ribbon promote highly synchronous multivesicular release at hair cell synapses. J Neurosci 31:16637-16650. CrossRef Medline

Harata NC, Aravanis AM, Tsien RW (2006) Kiss-and-run and full-collapse fusion as modes of exo-endocytosis in neurosecretion. J Neurochem 97: 1546-1570. CrossRef Medline

Harper CB, Martin S, Nguyen TH, Daniels SJ, Lavidis NA, Popoff MR, Hadzic G, Mariana A, Chau N, McCluskey A, Robinson PJ, Meunier FA (2011) Dynamin inhibition blocks botulinum neurotoxin type A endocytosis in neurons and delays botulism. J Biol Chem 286:35966-35976. CrossRef Medline

He L, Wu LG (2007) The debate on the kiss-and-run fusion at synapses. Trends Neurosci 30:447-455. CrossRef Medline

He L, Wu XS, Mohan R, Wu LG (2006) Two modes of fusion pore opening revealed by cell-attached recordings at the synapse. Nature 444:102-105. CrossRef Medline

Heidelberger R (2001) ATP is required at an early step in compensatory endocytosis in synaptic terminals. J Neurosci 21:6467-6474. Medline

Heidelberger R, Zhou ZY, Matthews G (2002) Multiple components of membrane retrieval in synaptic terminals revealed by changes in hydrostatic pressure. J Neurophysiol 88:2509-2517. CrossRef Medline

Heidelberger R, Thoreson WB, Witkovsky P (2005) Synaptic transmission at retinal ribbon synapses. Prog Retin Eye Res 24:682-720. CrossRef Medline

Holzhausen LC, Lewis AA, Cheong KK, Brockerhoff SE (2009) Differential role for synaptojanin 1 in rod and cone photoreceptors. J Comp Neurol 517:633-644. CrossRef Medline

Hsu SF, Jackson MB (1996) Rapid exocytosis and endocytosis in nerve terminals of the rat posterior pituitary. J Physiol 494:539-553. Medline

Hull C, von Gersdorff H (2004) Fast endocytosis is inhibited by GABAmediated chloride influx at a presynaptic terminal. Neuron 44:469-482. CrossRef Medline

Innocenti B, Heidelberger R (2008) Mechanisms contributing to tonic release at the cone photoreceptor ribbon synapse. J Neurophysiol 99:25-36. Medline

Jockusch WJ, Praefcke GJ, McMahon HT, Lagnado L (2005) Clathrindependent and clathrin-independent retrieval of synaptic vesicles in retinal bipolar cells. Neuron 46:869-878. CrossRef Medline

Johnson SL, Thomas MV, Kros CJ (2002) Membrane capacitance measurement using patch clamp with integrated self-balancing lock-in amplifier. Pflugers Arch 443:653-663. CrossRef Medline

Johnson SL, Forge A, Knipper M, Münkner S, Marcotti W (2008) Tonotopic variation in the calcium dependence of neurotransmitter release and vesicle pool replenishment at mammalian auditory ribbon synapses. J Neurosci 28:7670-7678. CrossRef Medline

Klyachko VA, Jackson MB (2002) Capacitance steps and fusion pores of small and large-dense-core vesicles in nerve terminals. Nature 418:89-92. CrossRef Medline

Linton JD, et al. (2010) Flow of energy in the outer retina in darkness and light. Proc Natl Acad Sci U S A 107:8599-8604. CrossRef Medline

Llobet A, Gallop JL, Burden JJ, Camdere G, Chandra P, Vallis Y, Hopkins CR, Lagnado L, McMahon HT (2011) Endophilin drives the fast mode of vesicle retrieval in a ribbon synapse. J Neurosci 31:8512-8519. CrossRef Medline

LoGiudice L, Matthews G (2007) Endocytosis at ribbon synapses. Traffic 8:1123-1128. CrossRef Medline

Macia E, Ehrlich M, Massol R, Boucrot E, Brunner C, Kirchhausen T (2006) Dynasore, a cell-permeable inhibitor of dynamin. Dev Cell 10:839-850. CrossRef Medline

Marks B, Stowell MH, Vallis Y, Mills IG, Gibson A, Hopkins CR, McMahon HT (2001) GTPase of dynamin and resulting conformational change are essential for endocytosis. Nature 410:231-235. CrossRef Medline

Mercer AJ, Rabl K, Riccardi GE, Brecha NC, Stella SL Jr, Thoreson WB (2011) Location of release sites and calcium-activated chloride channels relative to calcium channels at the photoreceptor ribbon synapse. J Neurophysiol 105:321-335. CrossRef Medline

Mercer AJ, Szalewski RJ, Jackman SL, Van Hook MJ, Thoreson WB (2012) Regulation of presynaptic strength by controlling $\mathrm{Ca}^{2+}$ channel mobility: effects of cholesterol depletion on release at the cone ribbon synapse. J Neurophysiol 107:3468-3478. CrossRef Medline

Moser T, Beutner D (2000) Kinetics of exocytosis and endocytosis at the cochlear inner hair cell afferent synapse of the mouse. Proc Natl Acad Sci U S A 97:883-888. CrossRef Medline

Neves G, Lagnado L (1999) The kinetics of exocytosis and endocytosis in the synaptic terminal of goldfish retinal bipolar cells. J Physiol 515:181-202. CrossRef Medline

Neves G, Gomis A, Lagnado L (2001) Calcium influx selects the fast mode of endocytosis in the synaptic terminal of retinal bipolar cells. Proc Natl Acad Sci U S A 98:15282-15287. CrossRef Medline

Newton AJ, Kirchhausen T, Murthy VN (2006) Inhibition of dynamin completely blocks compensatory synaptic vesicle endocytosis. Proc Natl Acad Sci U S A 103:17955-17960. CrossRef Medline

Pang JJ, Gao F, Barrow A, Jacoby RA, Wu SM (2008) How do tonic glutamatergic synapses evade receptor desensitization? J Physiol 586: 2889-2902. CrossRef Medline

Parsons TD, Lenzi D, Almers W, Roberts WM (1994) Calcium-triggered exocytosis and endocytosis in an isolated presynaptic cell: capacitance measurements in saccular hair cells. Neuron 13:875-883. CrossRef Medline

Rabl K, Cadetti L, Thoreson WB (2005) Kinetics of exocytosis is faster in cones than in rods. J Neurosci 25:4633-4640. CrossRef Medline

Rabl K, Cadetti L, Thoreson WB (2006) Paired-pulse depression at photoreceptor synapses. J Neurosci 26:2555-2563. CrossRef Medline

Rea R, Li J, Dharia A, Levitan ES, Sterling P, Kramer RH (2004) Streamlined synaptic vesicle cycle in cone photoreceptor terminals. Neuron 41:755766. CrossRef Medline

Renden R, von Gersdorff H (2007) Synaptic vesicle endocytosis at a CNS nerve terminal: faster kinetics at physiological temperatures and increased endocytic capacity during maturation. J Neurophysiol 98:3349-3359. CrossRef Medline

Rieke F, Schwartz EA (1996) Asynchronous transmitter release: control of exocytosis and endocytosis at the salamander rod synapse. J Physiol 493 : 1-8. Medline

Ripps H, Shakib M, MacDonald ED (1976) Peroxidase uptake by photoreceptor terminals of the skate retina. J Cell Biol 70:86-96. CrossRef Medline

Roux A, Uyhazi K, Frost A, De Camilli P (2006) GTP-dependent twisting of dynamin implicates constriction and tension in membrane fission. Nature 441:528-531. CrossRef Medline

Rowan MJ, Ripps H, Shen W (2010) Fast glutamate uptake via EAAT2 shapes the cone-mediated light offset response in bipolar cells. J Physiol 588:3943-3956. CrossRef Medline

Royle SJ, Lagnado L (2003) Endocytosis at the synaptic terminal. J Physiol 553:345-355. CrossRef Medline

Royle SJ, Lagnado L (2010) Clathrin-mediated endocytosis at the synaptic 
terminal: bridging the gap between physiology and molecules. Traffic 11:1489-1497. CrossRef Medline

Santos-Sacchi J, Kakehata S, Takahashi S (1998) Effects of membrane potential on the voltage dependence of motility-related charge in outer hair cells of the guinea-pig. J Physiol 510:225-235. CrossRef Medline

Schacher S, Holtzman E, Hood DC (1976) Synaptic activity of frog retinal photoreceptors. A peroxidase uptake study. J Cell Biol 70:178-192. CrossRef Medline

Schaeffer SF, Raviola E (1978) Membrane recycling in the cone cell endings of the turtle retina. J Cell Biol 79:802-825. CrossRef Medline

Schmitz F (2009) The making of synaptic ribbons: how they are built and what they do. Neuroscientist 15:611-624. CrossRef Medline

Schmitz F, Königstorfer A, Südhof TC (2000) RIBEYE, a component of synaptic ribbons: a protein's journey through evolution provides insight into synaptic ribbon function. Neuron 28:857-872. CrossRef Medline

Schnee ME, Castellano-Muñoz M, Kong JH, Santos-Sacchi J, Ricci AJ (2011) Tracking vesicle fusion from hair cell ribbon synapses using a high frequency, dual sine wave stimulus paradigm. Commun Integr Biol 4:785787. Medline

Sherry DM, Heidelberger R (2005) Distribution of proteins associated with synaptic vesicle endocytosis in the mouse and goldfish retina. J Comp Neurol 484:440-457. CrossRef Medline

Shupliakov O, Löw P, Grabs D, Gad H, Chen H, David C, Takei K, De Camilli P, Brodin L (1997) Synaptic vesicle endocytosis impaired by disruption of dynamin-SH3 domain interactions. Science 276:259-263. CrossRef Medline

Singer JH, Diamond JS (2003) Sustained $\mathrm{Ca}^{2+}$ entry elicits transient postsynaptic currents at a retinal ribbon synapse. J Neurosci 23:10923-10933. Medline

Smith SM, Renden R, von Gersdorff H (2008) Synaptic vesicle endocytosis: fast and slow modes of membrane retrieval. Trends Neurosci 31:559-568. CrossRef Medline

Snellman J, Mehta B, Babai N, Bartoletti TM, Akmentin W, Francis A, Matthews G, Thoreson W, Zenisek D (2011) Acute destruction of the synaptic ribbon reveals a role for the ribbon in vesicle priming. Nat Neurosci 14:1135-1141. CrossRef Medline

Stevens CF, Williams JH (2000) "Kiss and run" exocytosis at hippocampal synapses. Proc Natl Acad Sci U S A 97:12828-12833. CrossRef Medline

Sun JY, Wu LG (2001) Fast kinetics of exocytosis revealed by simultaneous measurements of presynaptic capacitance and postsynaptic currents at a central synapse. Neuron 30:171-182. CrossRef Medline

Sweitzer SM, Hinshaw JE (1998) Dynamin undergoes a GTP-dependent conformational change causing vesiculation. Cell 93:1021-1029. CrossRef Medline

Thomas P, Lee AK, Wong JG, Almers W (1994) A triggered mechanism retrieves membrane in seconds after $\mathrm{Ca}^{2+}$-stimulated exocytosis in single pituitary cells. J Cell Biol 124:667-675. CrossRef Medline

Thoreson WB, Rabl K, Townes-Anderson E, Heidelberger R (2004) A highly $\mathrm{Ca}^{2+}$-sensitive pool of vesicles contributes to linearity at the rod photoreceptor synapse. Neuron 42:595-605. CrossRef Medline

Ullrich B, Südhof TC (1994) Distribution of synaptic markers in the retina: implications for synaptic vesicle traffic in ribbon synapses. J Physiol Paris 88:249-257. CrossRef Medline

Van Epps HA, Hayashi M, Lucast L, Stearns GW, Hurley JB, De Camilli P, Brockerhoff SE (2004) The zebrafish nrc mutant reveals a role for the polyphosphoinositide phosphatase synaptojanin 1 in cone photoreceptor ribbon anchoring. J Neurosci 24:8641-8650. CrossRef Medline

Van Hook MJ, Thoreson WB (2012) Simultaneous whole cell recordings from photoreceptors and second-order neurons in an amphibian retinal slice preparation. J Vis Exp, in press.

von Gersdorff H, Matthews G (1994a) Dynamics of synaptic vesicle fusion and membrane retrieval in synaptic terminals. Nature 367:735-739. CrossRef Medline

von Gersdorff H, Matthews G (1994b) Inhibition of endocytosis by elevated internal calcium in a synaptic terminal. Nature 370:652-655. CrossRef Medline

von Gersdorff H, Sakaba T, Berglund K, Tachibana M (1998) Submillisecond kinetics of glutamate release from a sensory synapse. Neuron 21: 1177-1188. CrossRef Medline

Wang CT, Lu JC, Bai J, Chang PY, Martin TF, Chapman ER, Jackson MB (2003) Different domains of synaptotagmin control the choice between kiss-and-run and full fusion. Nature 424:943-947. CrossRef Medline

Ward SM, Kenyon JL (2000) The spatial relationship between $\mathrm{Ca}^{2+}$ channels and $\mathrm{Ca}^{2+}$-activated channels and the function of $\mathrm{Ca}^{2+}$-buffering in avian sensory neurons. Cell Calcium 28:233-246. CrossRef Medline

Wu LG (2004) Kinetic regulation of vesicle endocytosis at synapses. Trends Neurosci 27:548-554. CrossRef Medline

Wu LG, Ryan TA, Lagnado L (2007) Modes of vesicle retrieval at ribbon synapses, calyx-type synapses and small central synapses. J Neurosci 27 : 11793-11802. CrossRef Medline

Wu W, Xu J, Wu XS, Wu LG (2005) Activity-dependent acceleration of endocytosis at a central synapse. J Neurosci 25:11676-11683. CrossRef Medline

Wu XS, McNeil BD, Xu J, Fan J, Xue L, Melicoff E, Adachi R, Bai L, Wu LG (2009) $\mathrm{Ca}^{2+}$ and calmodulin initiate all forms of endocytosis during depolarization at a nerve terminal. Nat Neurosci 12:1003-1010. CrossRef Medline

Xu J, McNeil B, Wu W, Nees D, Bai L, Wu LG (2008) GTP-independent rapid and slow endocytosis at a central synapse. Nat Neurosci 11:45-53. CrossRef Medline

Yamashita $\mathrm{T}$ (2012) $\mathrm{Ca}^{2+}$-dependent regulation of synaptic vesicle endocytosis. Neurosci Res 73:1-7. CrossRef Medline

Yamashita T, Hige T, Takahashi T (2005) Vesicle endocytosis requires dynamin-dependent GTP hydrolysis at a fast CNS synapse. Science 307: 124-127. CrossRef Medline

Yao J, Kwon SE, Gaffaney JD, Dunning FM, Chapman ER (2012a) Uncoupling the roles of synaptotagmin I during endo- and exocytosis of synaptic vesicles. Nat Neurosci 15:243-249. CrossRef Medline

Yao LH, Rao Y, Varga K, Wang CY, Xiao P, Lindau M, Gong LW (2012b) Synaptotagmin 1 is necessary for the $\mathrm{Ca}^{2+}$ dependence of clathrinmediated endocytosis. J Neurosci 32:3778-3785. CrossRef Medline

Zampighi GA, Schietroma C, Zampighi LM, Woodruff M, Wright EM, Brecha NC (2011) Conical tomography of a ribbon synapse: structural evidence for vesicle fusion. PLoS One 6:e16944. CrossRef Medline

Zenisek D, Steyer JA, Feldman ME, Almers W (2002) A membrane marker leaves synaptic vesicles in milliseconds after exocytosis in retinal bipolar cells. Neuron 35:1085-1097. CrossRef Medline

Zhang JZ, Davletov BA, Südhof TC, Anderson RG (1994) Synaptotagmin I is a high affinity receptor for clathrin AP-2: implications for membrane recycling. Cell 78:751-760. CrossRef Medline 